\title{
On the Edge? Deserts, Oceans, Islands
}

Margaret Jolly

\section{Lake Mungo, New Year I999-2000}

On the edge? Or in the center? The sand shimmers, iridescent white, but then with the setting sun glows ocher, pink, red. We are climbing up this vast wall of sand, through luminescent outcrops formed from the long bake of the sun and the constant rush of the wind. The sand feels solid and crisp on my soles, the sand drifts and hurls itself from the edges of precipices, the sand envelops me as I tumble down its warm folds. This vast lunette of shifting dunes formed at the edges of what was once a lake, a lake teeming with freshwater fish, crayfish, and many, many mussels. A huge lake on the edges of which Aboriginal Australians camped and ate their fill as recently as 15,000 years ago. In 1999 the remains of Mungo Lady and Mungo Man were dated by the latest techniques of thermoluminescence and accelerated spectrometry to at least 56,000 and as much as 68,000 years before the present. I have seen artist's recreations of that abundant life in the pages of Australian Geographic. ${ }^{1}$ Brian Hunt, our Aboriginal guide, has shown us the delicate traces of ancient fish dinners, the smudge of carbon, the ivory of tiny fish bones poking out of the sand. The wind, the prehistorian who does not ask permission, excavates, revealing the deeper and deeper strata of human occupation of this country. Where there was once water there is now red earth and the shimmering grey-blue of salt bush. The horizon is endless and I feel the curve of the world, embraced and comforted by the vastness of this place and by Brian's sad political ballads, upbeat hymns, and sexy, sentimental country music. But why, when I clamber up these dunes after driving over a thousand kilometers inland do I expect to see the ocean, the deep blue swell of the Pacific? Why am I momentarily shocked to discover that where the sand suddenly ends, beyond the rim of the lunette, is not ocean

The Contemporary Pacific, Volume 13, Number 2, Fall 200I, 4I7-466

(C) 200 I by University of Hawai'i Press 
but a greener patch of kunai desert grasses, mallee, and pearl bluebush, sipping the water of occasional rains?

I am here to avoid the millennial place of that other edge, the edge of the eastern seaboard of Australia, where the hype and the fear of the end of the century, the end of the millennium is being celebrated. There I could witness a fever of fireworks, circus gymnasts abseiling the concrete sails of the Opera House as if they were canyons, and hear a medley of popular songs accompany the surreal movements of huge, inflated, illuminated simulacra of fish, octopus, and lobsters on the waters of Sydney Harbour. As midnight comes and goes, the lights on the Harbor Bridge move from the grimace of a forced smile to proclaim the word "Eternity." Oh yeah? Why in the thrill of this millennial moment did I not want to be here, on the edge, but yearn to go the center, to the "outback"?

I should not mislead you-it was not that I sought and found that purifying experience of an austere desert ecology, the exhilaration of sleeping under the stars. I slept in a comfy bed in an air-conditioned cabin replete with kitchen and bathroom. Nor did I find the ancient grandeur of an indigenous landscape. For in the dry bed of that once-was-lake, several generations of white Australian families farmed sheep. Local Aboriginal people were dispossessed of their country, massacred by guns and poisoned water holes, and in the midst of pastoralist and mission invasions, found it hard to hunt the kangaroos, wallaby, and emus, to gather the yams and seeds, to live like the old people. They worked at the sheep station too, and the heritage shearing shed, built in I869, is for Brian as much a part of Aboriginal as white settler history. And, from the late-nineteenth century some Chinese immigrants, who did not succeed in finding gold in Bendigo or Ballarat, cooked Asian style "bush tucker" ${ }^{2}$ and worked in outback stations like this. The local Chinese workers called these sand dunes the Walls of China, and the name has stuck. We sipped champagne and acted up on the ancient sands. We retreated to our air-conditioned cabins to watch the millennial fever on television as it spread in Sydney, London, Paris, Washington, New York.

\section{Shifty Ground and Still Oceans}

I tell these millennial travelers' tales not to displace the question of "native cultural studies" in the Pacific from the edge of California to the center of Australia, but because I want to situate my understanding in my being a white Australian in a settler colony and a woman who usually lives on the edge of the Pacific and rarely in the islands. I tell this story to reflect on 
how far our imagined geographies of edges and centers, of peripheries and interiors are mirages of the geopolitics of our present. ${ }^{3}$ Is Lake Mungo "in the center" or is it "outback"?

Reading the prospectus for the symposium from which this volume derives, I was delighted with the way our organizers connected the nervous tension of plate tectonics with contemporary identity politics-the fraught connection of ground and body. "What happens when the grounds of indigeneity... get too fixed, or move too far?" Their evocation of California's seismic stress renders the ground fluid and shifty. But they also allude to that other ground, the ocean, as celebrated in Epeli Hau'ofa's recent writings ( $1994,1998,2000$ ). His inspiring vision of the Pacific transforms the imagined isolation and vastness separating the islands into a homey expanse of connection. For him the sea is as much inside the bodies of Islanders as it is their connecting fluid of passage, in world-traveling canoes or jumbo jets, the still center of an ocean of experience they navigate (see also Clifford, 476).

Partly in conversation with Hau'ofa's essays, I challenge the way in which Pacific peoples are often represented as simply rooted, as grounded in the land, partitioned by the borders of a village or an island, as static in place and time while foreigners-Europeans or Asians-are represented as mobile explorers, as invasive strangers. Such spatial language often transforms into a temporal language whereby Islanders are portrayed as stuck in times past, confined by the boundaries of tradition while foreigners are constructed as the agents of change and transformation-the voyagers, the planters, the labor traders, the missionaries, the colonial officials, the development agents. Even those theories hostile to colonial and capitalist penetration can portray the process as one of a rapacious mobile capital, engulfing Islanders who are imaged as hapless victims, trapped in the closed inertia of community, or lost in nostalgic recollections of times past. ${ }^{4}$

But Pacific peoples have always been on the move in both senses, as well as being rooted and settled in their islands. Long generations of Islanders have embodied this dialectical tension, between movement and settlement, between routes and roots (to use the current idiom, which to my ear, sounds better as homophones in Australian English). It is most powerfully witnessed in the extraordinary history of the Austronesianspeaking peoples moving from their original homelands in south China (possibly Taiwan) across the vast liquid expanse of the Pacific Ocean. This extended process of long-distance navigation in oceangoing canoes, without charts and compasses-navigating by the stars, the swells of the 
ocean and its currents, the direction and strength of the prevailing winds, the movement of birds, the subtle signs of land-spread settlers from the western islands of what are now Papua New Guinea, the Solomons, New Caledonia, Vanuatu, and Fiji, north to Palau, Guam, and the Marshalls, east to $S$ moa, Tonga, the Cook Islands, and Rapanui, south to Aotearoa New Zealand and north to Hawai' $i{ }^{5}$ When these first and successive Austronesian voyagers stayed and settled, they cultivated not just new crops, but deep attachments to the land, attachments celebrated in genealogies of ancestral connection between people and place. They populated most of the habitable islands, not through chance and contingency, not by being blown or drifting as some foreign cynics earlier suggested, but by a highly skilled and motivated practice of sailing and settlement, in which "home" was as much the ocean as the land, and where the canoe was imagined as the still point and the world moving (Finney I994). These "voyages of discovery" were made several centuries before journeys by European explorers-de Quiros, de Bougainville, Cook, and many others - who are still too often proclaimed, in racist ignorance or hubris, the "discoverers." 6

Little wonder that these extraordinary ancestral navigations have inspired not only a sense of pride in the ancients of Oceania, but celebration in the lives of contemporary Pacific Islanders, expressed not just in oral traditions, but in the practice of contemporary long distance navigations. Since the I970s, throughout Polynesia and Micronesia, there has been a recuperation of the ancient arts of building long-distance, oceangoing canoes and of the complicated techniques of their navigation. In Hawai'i a vigorous revival has been guided by master sailors like Nainoa Thompson. They have traveled to Tahiti, the Cook Islands, and, most recently, to Rapanui. The $H k l e^{c} a$, that stunning double-hulled oceangoing canoe, arguably exceeds the replica of Cook's Endeavour in the extent and the portent of its travels (but see Dening 1998). In Hawai'i schoolchildren visit the canoe and are instructed in the arts of sailing, thereby learning Hawaiian concepts and ancestral religious philosophies in a practical way. At the Center for Hawaiian Studies at the University of Hawai' $i$ at $M$ noa, the ancient skills of navigation are taught in ways that combine cultural revival with sovereignty sentiments.

There has been a parallel resurgence of canoe-building and navigation in Micronesia, in the Cook Islands, and in Aotearoa New Zealand. The Micronesian revival is consummately conveyed in the film written and directed by Vicente Diaz, Sacred Vessels: Navigating Tradition and Iden- 
tity in Micronesia. On the soundtrack, the first voice we hear is the deep, sonorous male bass of the canoe (with a female echo, seemingly the voice of the outrigger!): "I carried the first people to these islands." 7 Then we hear the more familiar voice of Diaz, reflecting that after years of study in Hawai' $i$ and California he discovered the biggest truths "in my own backyard"-back on Guam. It shows us contemporary master canoe-builders on Polowat and Guam. Gaining the knowledge of canoe construction and navigation requires both martial discipline and sacred sensibility-one is ordained like a priest, one becomes like a "superman" of the spirit. Men are linked to the sea, and women to the land (land is passed through mothers). Diaz insists on the canoe as cultural foundation and historical metaphor, a conduit of connection between old traditions and new horizons: "otherwise you are just hanging from a tree, you don't have any roots." Finding roots depends on making routes.

Such "voyages of rediscovery," such cultural odysseys, as Ben Finney (I994) adroitly called them, have inspired Islanders in many countries and proved crucial to a new vision of a sea of connectedness rather than one of isolated islands. This new vision is often created in defiance of the languages of colonial partitions, the borders created by the ethnological typifications of Melanesia, Polynesia, and Micronesia, or in resistance to the discourses of developmentalism (see Escobar 1995), which typically image the Pacific as a proliferation of small states characterized by isolation and by lack.

This brings me back to Epeli Hau'ofa's influential, alternative vision of Oceania (1994, I998, 2000). He writes in defiance of the orthodoxies of foreign experts and especially some economists emanating from the World Bank and the Australian National University who constantly typify the Pacific in terms of what it lacks, not only the palpable lack of development or growth, but the deficiencies of scale, isolation and dependency, small islands, tiny populations, remote from world centers but increasingly dependent on them. What Hau'ofa has stressed instead is not the dots of land but the connecting sea, the many ways in which, despite the diversities of languages and cultures, there is an ocean, a liquid integument of common experience. He depicts those who live in the privileged circuits - politicians, bureaucrats, diplomats, soldiers, development agents, and academics-as preoccupied with the questions of national borders, sovereignty, and dependency. Those who live in a less rarefied atmospherethe people, the peasants, the proletarians-are able, he thinks, to sustain a less dismal, less aporetic vision of life. 
He acknowledges that he earlier wrote in the language of underdevelopment and dependency. But he is alert to how the constant reiteration of the facts of colonial domination and of perduring dependence generate a sense of hopelessness. Beyond the belittlement of Christian missionaries condemning Oceanic cultures as heathen, of colonial authorities infantilizing adults as "boys" and "girls," he detects belittlement in depictions of the smallness and insularity of Pacific states and of some as MIRAB societies, pitiful microstates condemned to dependence on "migration, remittances, aid and bureaucracy." Hau'ofa's epiphany came in part from his teaching at the University of the South Pacific. "The faces of my students continued to haunt me mercilessly.... What kind of teaching is it to stand up in front of young people from your own region, people you claim as your own, who have come to university with high hopes for the future, and you tell them that our countries are hopeless? Is this not what neocolonialism is all about?" (I994, I50-I5I).

Hau'ofa inspires hope by a contrary image of Pacific peoples, not as confined to and by their islands, but as motivated to be mobile, like the navigators of old. The original Austronesian voyaging into the Pacific was no doubt a process of world enlargement. Hau'ofa's vision of contemporary world enlargement does not just connect such voyages in the past with their reenactment in the present, but embraces the broader movements of persons, objects, and ideas through Oceania and beyond.

Inspiring as his vision is, it tends to celebrate a particular subject position, that of a "world traveler." It echoes the particularities of his own life history. ${ }^{8}$ It may be an appropriate vision for those many Tongans, Samoans, Cook Islanders, Niueans, and Hawaiians who live between and across the borders of states, who have settled around the edge of this ocean, variously in Canada and the United States, in Australia, and in Aotearoa New Zealand. Such celebrations of ancient voyages seem to meld with the experiences of contemporary migration. And yet modern "world travelers" are rather more cramped-they typically follow older colonial circuits and their journeys are plotted by the cosmology of global capitalism. Such migrations entail complex motivations and rarely result in easy wealth or ready acceptance. Successive generations of Oceanic migrants have encountered poverty and racism in their countries of adoption.

So, I wonder how far this is a compelling vision for all Islanders and especially for those people of the southwest Pacific who, because of border patrols by nation states, the exclusionary policies of migration, and sheer poverty, are not able, even if they so desired, to move from their 
newly independent states to other parts of the Pacific, or to North America, Australia, or Aotearoa New Zealand. They still travel, but in worlds of smaller scale. They often migrate in more localized movements within the world of the archipelago or nation-state-but their routes stop at Port Moresby, Port Vila, or Honiara. They travel in trucks or light local planes but they do not board the jumbo jets. They do not move on to Auckland, Sydney, Honolulu, San Francisco, or Salt Lake City. ${ }^{9}$

My sense of this regional difference was distilled in an experience of a meeting in Suva in 1997. Here were gathered representatives of the museums and cultural centers of the several states of the Pacific (organized by unesco and the World Heritage Centre in Paris, to discuss the potential of listing of new world heritage sites in the region). In the plenary discussions, several of the representatives from Papua New Guinea, the Solomons, and Vanuatu opposed what they saw as an undue emphasis on the ocean and navigation on the part of the Polynesian and Micronesian delegates. The representative from Papua New Guinea pointed out that many Highlanders from the interior of his country had no sense of ancestral connections to the ocean, no knowledge of how to make canoes, and indeed had never seen the sea. There is a big difference between living in the interior of a large mountainous island and living in archipelagoes of smaller islands or on coral atolls.

But as I heard these dialogues it was not just an articulation of differences in geographical position, nor an insistence on being Melanesian as against Polynesian or Micronesian. Such conversations also reflected differences between Islanders in how they were situated in the global geopolitics of state forms and migration patterns. All those who spoke in this way came from the independent states of the southwest Pacific-characterized by the demographic dominance of indigenous people, the predominance of customary local landholding in the face of huge pressures for privatization and commoditization, and the difficult negotiations, and sometimes violent confrontations, between national, regional, and local claims for being "people of the place." 10 Although Papua New Guineans, Solomon Islanders, and ni-Vanuatu migrate much within their nations, only the most highly educated and wealthy travel overseas, and of these only a very few live permanently elsewhere. They are, unlike Tongans, Samoans, or Hawaiians, not much into "world traveling." At least not now, for they once were.

I refer not just to those ancient voyages by the ancestors of Austronesian and Papuan speaking people but that more recent history of "world traveling" that characterized a previous epoch of globalization, an earlier 
period of colonizing capitalism. From the mid-nineteenth century well into the twentieth, there was a huge and vigorous labor trade in which over one hundred thousand people, ancestors of contemporary ni-Vanuatu, Solomon Islanders, and Papua New Guineans, moved as indentured workers to cultivate plantations of sugar, cotton, coconuts, and pineapples in Queensland (the "Deep North" of Australia), in New Caledonia, in Fiji, in $S$ moa, and in Hawai' $i{ }^{11}$ Such nineteenth-century movements mainly involved young men (and some young women) laboring on contracts of indenture. This labor trade, or as Shineberg's recent book prefers, "people trade" (I999), has been much written and talked about, and much debated between those who stress the free will of the contracting recruits, responding to the allure of foreign goods and foreign places, and those who see it rather as a history of kidnap, bonded labor, and coercive discipline, approximating "slavery." 12

Such movements of indentured Melanesian workers were arrested early in the twentieth century. Unlike the Indians in Fiji, the Filipinos, Portuguese, and Japanese in Hawai'i most were sent back "home" or, less gently, deported. In Australia this occurred at the turn of the century with the federation of the diverse colonies and the ugly politics of the passing of the Immigration Restriction Act of I90I (the origin of the infamous White Australia Policy). ${ }^{13}$ A few laborers and their descendants were granted rights to remain, many more fled and escaped deportation. These South Sea Islanders as they call themselves, number about forty thousand in Australia today. In 1994 they won recognition as a minority, distinct from indigenous Australians, Aboriginals, and Torres Strait Islanders (although all these peoples intermarry and mix, especially in Queensland).

The relation of indigeneity and diaspora, of roots and routes, is not just that of an old perduring colonialism between Aboriginal and white Australians, between $\mathrm{M}$ ori and Pakeha in Aotearoa New Zealand, between Kanaka" iwi and haole in Hawai'i, but also that between "natives"between Hawaiians in Hawai'i and those in California, between Tongans in Tonga and those in Auckland or Salt Lake City, between ni-Vanuatu, Solomon Islanders, and Papua New Guineans living "rooted" in their islands, and those South Sea Islanders whose ancestors were "routed" to Queensland in the late-nineteenth century and who, having escaped forcible deportations by white Australia, live in the country towns and big cities of its eastern edge.

Yet, in discussing differences between Islanders we must be careful not to create new essentialist typifications based on that seductive dichotomy of "roots and routes" (see Clifford 1997 and Geertz 1998, which trans- 
forms Clifford's dialectic into dichotomy). Those who live in the islands celebrate both rootedness and local travel and movement. Those who have followed routes beyond the ocean still celebrate their roots back home. Pacific peoples live in both spatialities and contextually deploy metaphors of both groundedness and mobility, settlement and detachment to articulate their being in the world. But where they live, the specific places of their being, also matters. Divergent colonial histories and different contemporary $\mathrm{M}$ ori configurations of interest-between indigenes, white settlers, and migrants-mold how roots and routes are "articulated" in Clifford's sense (472, 477-484).

\section{“Roots" and "Routes" in Contemporary Arts}

I now consider the dialectics of indigeneity and diaspora in some contemporary artistic expressions in Vanuatu, New Caledonia, Aotearoa New Zealand, and Australia. Both "roots" and "routes" are articulated, but their relation, their "hooking together" is powerfully constrained by context-by whether Islanders live in independent states or settler colonies and by divergent histories of settlement and migration (see also Jolly I999a). In what follows I use the restrictive lens of four occasions of artistic expression in the Pacific: the Arts of Vanuatu exhibition, or Spirit Blong Bubu I Kam Bak at the Vanuatu Cultural Centre in Port Vila, June I996; the exhibitions for the opening of the Tjibaou Cultural Centre in Noumea in New Caledonia, June $1998 ;^{14}$ my impressions of Te Papa in Wellington in March and October I999 and July 2000; and some events of the Pacific Wave festival in Sydney in November I998. I focus on context rather than content but offer accompanying images to suggest the brilliance and beauty of the art and how relations between indigenes, settlers, and migrants are differently imaged in displays in these four cities-Vila, Noumea, Wellington, and Sydney.

\section{Port Vila - Arts of Vanuatu/Spirit Blong BUBU I KAM BAK}

In 1995 the new museum was opened in Port Vila, Vanuatu-an impressive structure with sloping peaked roof atop a hill overlooking Vila Harbor and Iririki Island (erstwhile home of the British resident commissioner, now an upmarket tourist resort). Through this relocation from its earlier waterfront locale, its precious collections of old artifacts, books, photographs, and films are no longer so exposed to the ravages of cyclones and 
tidal waves. Moreover, it is strategically proximate to the national parliament complex, the nakamal (men's house) of the Malvatumauri (the Council of Chiefs), and the recently completed offices of the Vanuatu National Council of Women (figure I). ${ }^{15}$

For the opening, Director of the Vanuatu Cultural Centre Ralph Regenvanu and his staff assembled, from the several islands of the archipelago, rituals of dance and music and clowning routines from the repertoire for initiations, weddings, and grade-taking and demonstrations of indigenous artistic techniques such as wood carving and pandanus weaving and dyeing. But there were also video screenings and concerts of Christian hymns and string-band music. Visiting dance troupes and musicians came from the Solomon Islands and New Caledonia.

By contrast, the Arts of Vanuatu exhibition a year later, with its heavy involvement of European and Australian curators, advisers, and aid money, more rigorously segregated indigenous and introduced artistic forms, as much as it separated the creations of men and of women. Indigenous older artifacts formed the core of this exhibit. The works were drawn, in large part, from a stunning collection made by the Swiss ethnol-

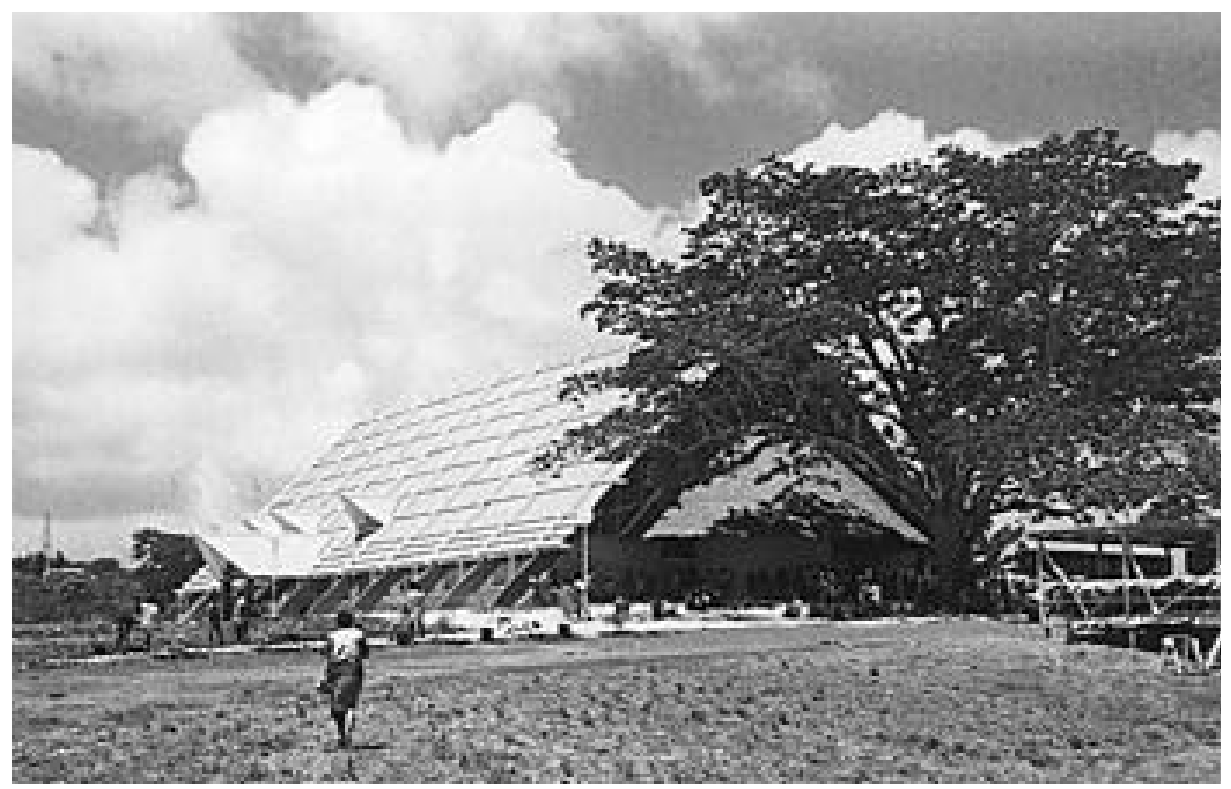

FigURE I. National Museum of Vanuatu. (From Kaufmann 1997, 36, courtesy of Christian Kaufmann, Museum der Kulturen, Basel, Switzerland) 
ogist Felix Speiser from I9I0 to I9I2 and held primarily in the Museum of Basel. ${ }^{16}$ The show, curated by Christian Kaufmann, opened in Port Vila in June 1996 before it went back to Basel in March 1997 and then Paris in I998. In Vila, the Arts of Vanuatu exhibition was called in Bislama (pidgin, the lingua franca) Spirit blong bubu $i$ kam bak (the spirits of the ancestors have returned).

The privileged presences were wooden sculptures and canoes, funerary effigies, masks, slit-gongs, pig-killing hammers, bows and arrows, and war clubs made by men. From this rich array certain objects are still etched in my memory - the extraordinary beauty of the elongated and etiolated "blue man" from Malo, with drooping white face and penis, beneath a burdensome headdress (figure 2); the fragility of a spider's web mask from south Malakula, its deep green and white spotted face with a grimacing dentition of pig tusks, its head bristling with protruding spikes of tree fern; the curve of the tamate caps from the Banks Islands, with their coconut spathe painted with white, black, and rusty ochers and woven with leaves and small shells; the extraordinary presence of a rambaramb, a funerary effigy from south Malakula, the painted overmodeled skull of the deceased adorned with rooster plumes, its vegetable body striped and circled in indigo, orange, and white and its black arms dripping with valuable pigs' tusks.

Perhaps most exquisite were the finely incised earrings, worn by women and men from the Banks, Maewo, and Ambae-pencil-thin bamboo with abstract black motifs (see Huffman 1996). Surely most dangerous were small carved figurines of stone and coral-embodying ancestral power that might be used for the fertility of crops and people (or their infertility). In Basel these were partitioned off behind a huge enlargement of a Speiser photograph of boys sitting on the fence of a men's house (nakamal) on Vao. Innocent viewers (in particular women) who might venture behind the partition were advised of their dangerous power. In Port Vila they were cordoned off in a more customary way, with coconut and cycas leaf fronds, and women were forbidden entry.

The superb display of tapa mats and belts, pandanus mats, skirts, penis sheaths, and baskets created by women (for the most part) were displayed separately in both venues: in Basel on a separate level, and in Vila on the upper floor. Most amazing to my eye was a small pandanus mat from Efate, its aged yellow turmeric-colored base and fibers dyed rust and plaited in an asymmetrical geometry that dazzled and deluded the eye as effectively as any Escher drawing (figure 3). Better known from the con- 
temporary writings of Annie Walter (1996) and Lissant Bolton (I996) were early examples of pandanus mats from Pentecost and Ambae (mat skirts and penis sheaths for clothing, sleeping mats, and exchange mats), many with maroon designs made with banana-leaf stencils and reverse-dyeing techniques, with long dyed fringes or plaited braids. Mats in similar named styles are still made today in the northern islands. By contrast, decorated tapa cloths previously common in the southern islands, ceased to be made as imported cloth was introduced from the nineteenth century onward. From the Australian Museum and the British Museum came early examples of large tapa cloths made by women from Efate and Erromango, with their beautiful abstract designs of brown, ocher, and black (figure 4 ). ${ }^{17}$

Figure 2. The blue man of Malo. (From Bonnemaison and others 1994,26 , courtesy of Crawford House Publishing, Bathurst NSw)

\section{At far right:}

FIgURE 3. Efate pandanus mat. (FromBonnemaison and others I994, I 8, courtesy of Crawford House Publishing, Bathurst NSw)
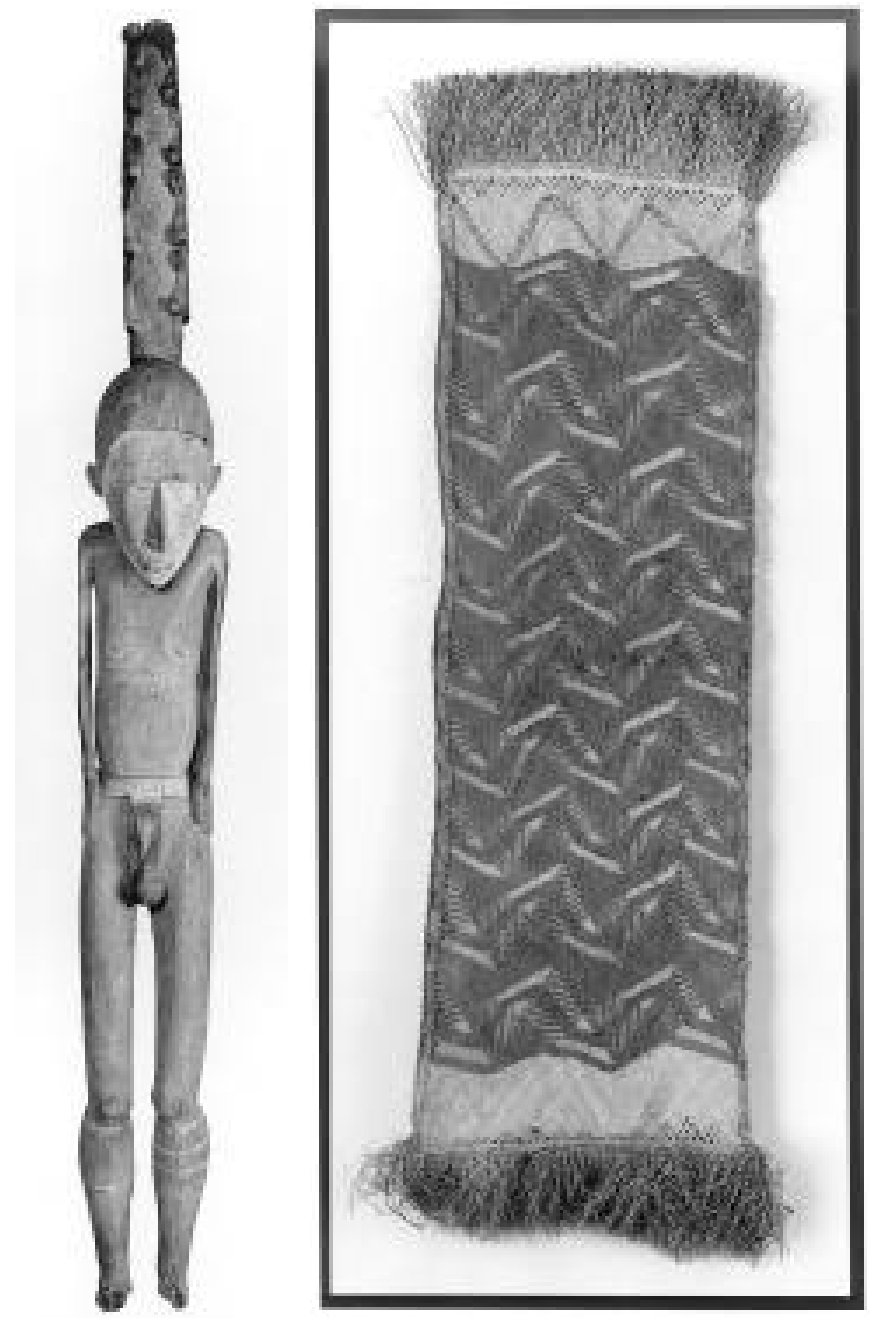
Again in a separated space were a few "contemporary" works by niVanuatu artists- "contemporary" in the contested sense of being creations not just by living artists but in idioms that embodied a creative conjugation of local and "western" aesthetics. These included paintings by Michel Busai, Ali Pilioko, and Ralph Regenvanu, carvings by Emmanuel Watt, clay pots by Eric Natuoivi, and tapestries by Juliette Pita. Impressive

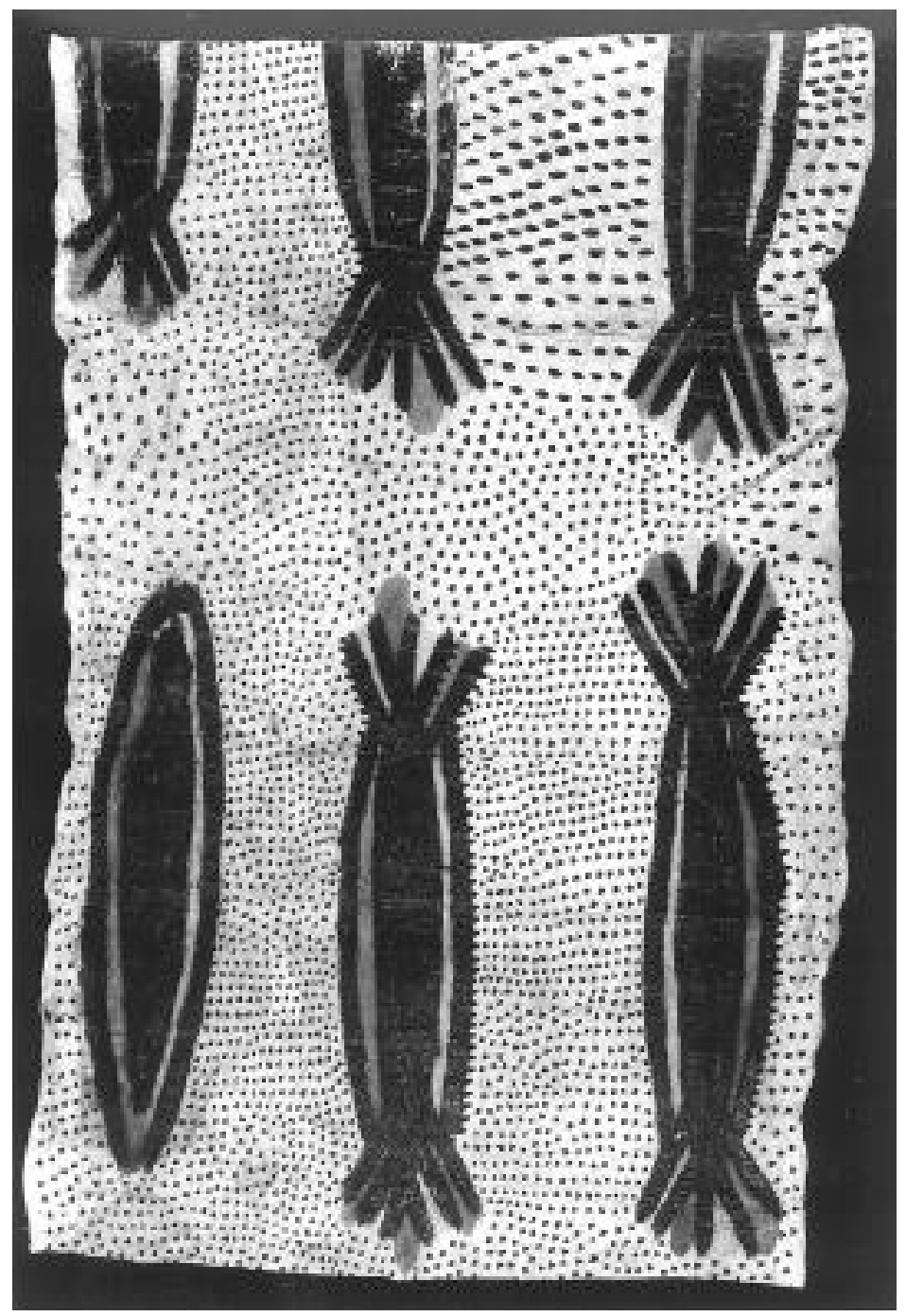

Figure 4. Tapa from Erromango. (From Bonnemaison and others I994, I34, courtesy of Crawford House Publishing, Bathurst NSw) 
as many of these works were, these contemporary arts were not the privileged subject of curatorial or audience attention. The older, indigenous "arts of Vanuatu" were more celebrated-in Port Vila as inspiration for the imagination of an independent indigenous nation.

In the words of Ralph Regenvanu, director of the Vanuatu Cultural Centre, this exhibition reemphasized "at a critical juncture in the development of the post-colonial national discourse, the importance and contemporary relevance of certain aspects of our cultural heritage. The viewing of ancient and expatriated pieces of material culture by audiences whose own forebears had created them was reflected in the Bislama title of the Port Vila exhibition-Spirit blong bubu i kam bak" (I997, IO-II). In his view it displayed not only the richness of a past artistic heritage, but "demonstrated that exposure to photographs of aspects of life in Vanuatu in the early part of this century and to tangible pieces of art and material culture from this period can be particularly instrumental in formulating and affirming positive identities and inspiring creative ideas and forms of expression for the latest generations of ni-Vanuatu" (I997, I I). The exhibition was visited by about a third of the population of Vila (that is, around I4,000 people) and clearly captured the "imagination of the nation" as the title phrase passed into Bislama and was broadcast on the bodies of those wearing the T-shirt the Vanuatu Cultural Centre commissioned for the occasion. And yet, it seems, the title was interpreted too literally by some who wrongly believed that the objects had been repatriated for good. Moreover, some evangelical Christians considered the entire show to be the work of the devil, refused to go, and demanded it be closed. They were especially offended by the separate compartment into which women were forbidden entry, because it contained those dangerous stone sculptures used for the fertility (and infertility) of gardens and of people. But the majority of ni-Vanuatu Christians relished this superb celebration of the arts of earlier generations, and some aspired to reproduce such objects for future generations. In its ongoing work the Vanuatu Cultural Centre continued to emphasize not just displays but the work of indigenous fieldworkers in recording, recuperating, and perpetuating living kastom (tradition; Bolton 1999).

Much has been written about the mobile meanings of kastom in this state, which in 1980 achieved independence from the joint colonial control of Britain and France. ${ }^{18}$ Closely related to the value of kastom is the value of being man ples (Bislama for indigenous or local person). This phrase was prominent in the languages of anticolonialism and nationalism, and especially in those movements to reclaim alienated land from the 
colonizers and return it to its customary owners. The independent state was named Vanuatu - variously translated as "land standing up" or "eternal land." At independence, all land was returned to indigenes. Land continues to be held primarily not as a commodity through individual ownership as freehold title but rather through customary, collective forms of tenure or as many ni-Vanuatu prefer, "custodianship." Urban land, ground for offices, shops, and tourist developments, is held on long-term leases, despite the strenuous pressure from expatriate economists, World Bank advisers, and the like to change all this in the pursuit of "development" (see Rawlings 1999). Like Papua New Guinea and the Solomons, Vanuatu has a very high percentage of indigenes ( 96 percent) and a very small number of resident expatriates (primarily Europeans, Chinese, and Indo-Chinese). Most foreigners in Vanuatu are consultants or advisers on short sojourns, or tourists on very short holiday packages.

Indigeneity is strongly valued in both national and local contextsagainst the invasive forces of strangers-although Christianity is exempt from such deprecation, and is seen as foundational for ni-Vanuatu identity. In such talk the local is often invoked in the idiom of roots and especially the large spreading roots of the banyan tree, resistant and enduring, in contrast to flighty Europeans. But this does not mean a disavowal of routes-motivated mobility is good, especially for men. Past exchanges between islands in canoes, even shipboard journeys as indentured laborers and contemporary migrations to town, to Vila or Santo, are seen as potentially empowering journeys, for men at least. ${ }^{19}$

Noumea-Centre Culturel Jean-Marie TJIBAOU/NGAN JILA

Unlike its near neighbor Vanuatu, New Caledonia is still a colonial possession, still an overseas territory of metropolitan France. Unlike Vanuatu, where the indigenous population is demographically dominant, here Kanak number only about 44 percent. They cohabit with a large white French and métis population, with Islander migrants from other French territories, and with Asians, with whom they have at best uncertain alliances and at worst tensions and enmities. ${ }^{20}$ This is a country where the best land was long ago alienated from indigenous owners and remains so. The money, as well as the pollution generated by nickel mining, is visible in Noumea, which much more than Port Vila, Honiara, or Port Moresby feels like a white town.

The Kanak movement for independence, or at least recognition of 
Kanak precedence and autonomy, dates from the earliest days of colonization in 1853 . This movement was resisted by the French and culminated in the violent struggles of the I980s in which many died. In 1988 the Matignon Agreements were enacted in an effort at reconciliation, with promises of greater respect and recognition of indigenous culture, decentralization of power, and eventually a referendum on self-determination. ${ }^{21}$ Not long after, in 1989, Jean-Marie Tjibaou, the charismatic Kanak leader, was assassinated.22 He had long been pressing for a center for Kanak culture in Noumea and this idea was enshrined in the Matignon Agreements. The French government decided to fund this project generously and commissioned the Italian architect Renzo Piano to create "something very unusual, something very strong," in the words of Emmanuel Kasarhérou. The Tjibaou Cultural Centre was, according to Kasarhérou, its cultural director, envisaged simultaneously as "the recognition of Kanak culture and the souvenir of Jean-Marie Tjibaou." ${ }^{23}$ This "gift" from the French state was two years in design and three years in construction: it cost A $\$ 80$ million dollars and has an operating budget of about $\mathrm{A} \$ 8$ million dollars a year (Brown I998).

The architecture of Renzo Piano's building has been justifiably celebrated. ${ }^{24}$ It is a stunning series of ten ovoid pavilions, on the model of half-completed Kanak houses, made of superb hardwood, iroko, imported from Ghana but locally weathered and reinforced with a steel skeleton. The highest is 28 meters, the lowest 3 meters. They are congregated in three hubs or "villages" that run along a ridge, connected by a long, lowslung, glassed and louvered structure behind. They stand beyond a golf course, lonely on Tina Peninsula-a peninsula so windy and isolated it is said that no hotel developer desired it. ${ }^{25}$ But Piano knew his site-the rounded ribs face the prevailing tradewinds on the seaward lagoon, and you can hear wind playing through the wood, which resonates like a stringed instrument. ${ }^{26}$ On the leeward side, facing the tranquil inland lagoon, the building is lower, on a more intimate scale-as you walk you hear small birds scampering in the low bracken. From many parts of Noumea it is visible like a silent sentinel, glowing brilliant orange at dawn and dusk and eggshell brown in the middle of the day (figure 5).

Piano's site architect, William Vassal, explained that although Kanak people were involved in all stages of planning the center, they eschewed major involvement in the building. Piano saw the half-completed houses as an image of the half-completed struggle for Kanak independence, articulating aspirations for the future. This symbolism is important, but many 


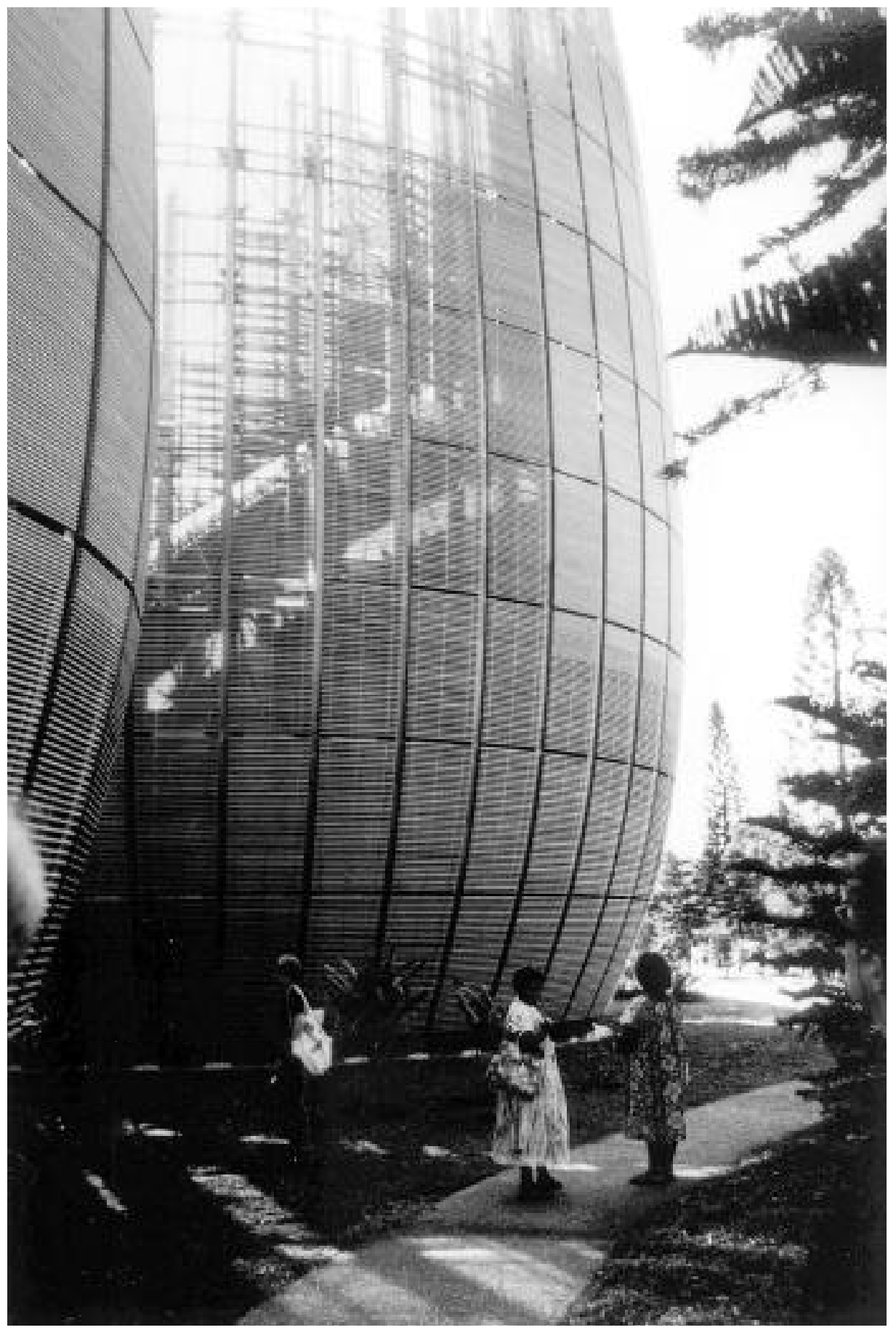

Figure 5. Tjibaou Cultural Centre, Ngan Jila, exterior view. (Margaret Jolly) 
Kanak consider the ground around just as, if not more, important. ${ }^{27}$ The area is cultivated with gardens, arranged along a winding path. They trace the five stages in the life of Téa Kanaké (the firstborn of all men, according to one Kanak story): the origin of beings, the earth that nourishes us, the land of the ancestors, the spirit world, and rebirth. In each of these garden spaces specific plants that mark the five successive stages are cultivated: the giant taro, the water yam, the column pine, the banyan, and the ironwood. A walk along this path traces and emulates the Kanak philosophy of life and growth, death and regeneration. It ends at the edge of the lagoon, in a boulder with a hole through which the spirits of the dead launch themselves into that other place (Kasahérou and Wedoye I998; figure 6).

The Tjibaou Cultural Centre is unsurpassed in the Pacific for its architectural splendor and its expensive, high-tech virtuosity. ${ }^{28}$ It sustains a singular stress on contemporary Pacific arts rather than the curating and display of older objects, as in the museum collections at Port Vila. There are about thirty older artifacts in the Bwenaado house (mainly masks, houseposts, and roof sculptures on loan from European museums), but most older Kanak artifacts are still housed in the Territorial Museum of New Caledonia in town. The emphasis in the Ngan Jila (house of riches) is rather on contemporary works by named artists in both indigenous and introduced genres. According to Emmanuel Kasarhérou this is faithful to Tjibaou's vision of Kanak culture not as frozen in the past, but as open and lived in. Its inaugural exhibitions also expressed a rather different configuration of ethnic relations to those in Port Vila. An exhibition of historical photographs and texts celebrating the life of Jean-Marie Tjibaou stressed the entanglement of Kanak and French culture, even as it documented the racism of the French and the violence of New Caledonia's colonial history. Both the ensemble of works already acquired and those made during the opening workshops, "Creating Together," stressed regional Pacific affinities. As Marie-Claude Tjibaou, the widow of Jean-Marie, and chair of the Agence de Développement de la Culture Kanak expressed it, the specificities of being Australian Aboriginal, Papua New Guinean, Samoan, or Solomon Islander recede in the face of shared experiences and "the need to open out to the world." She stressed common concerns to protect cultural heritage and environment against the ravages of development and nuclear testing (Ngan Jila I998).

Thus, Jinu, a room of seven large wooden sculptures housed not just Kili, a huge black awl created by Norman Song, a Caledonian sculptor, but artists from the Sepik in Papua New Guinea, from West Papua, from 


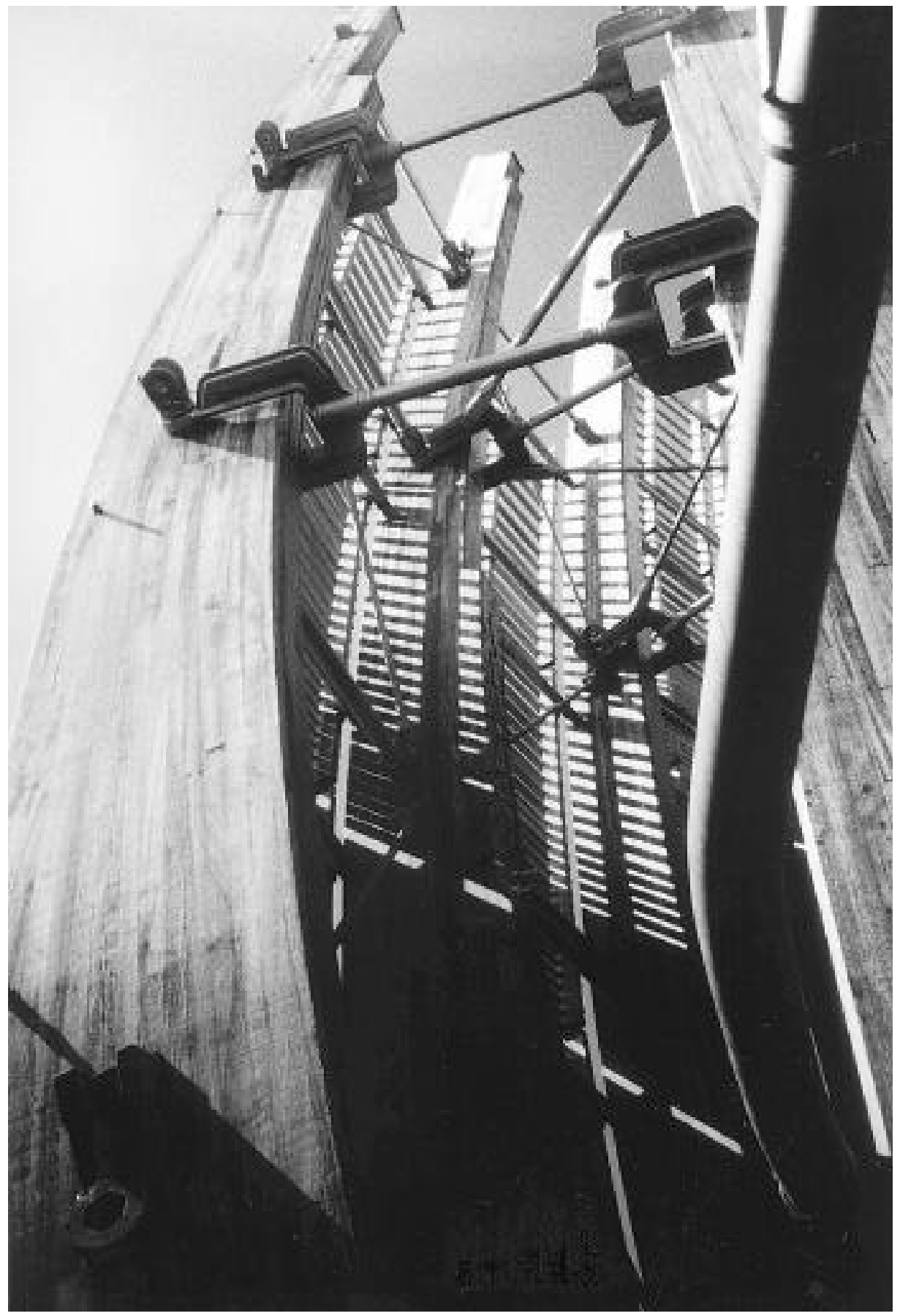

Figure 6. Tjibaou Cultural Centre, Ngan Jila, the steel skeleton within. (Margaret Jolly) 


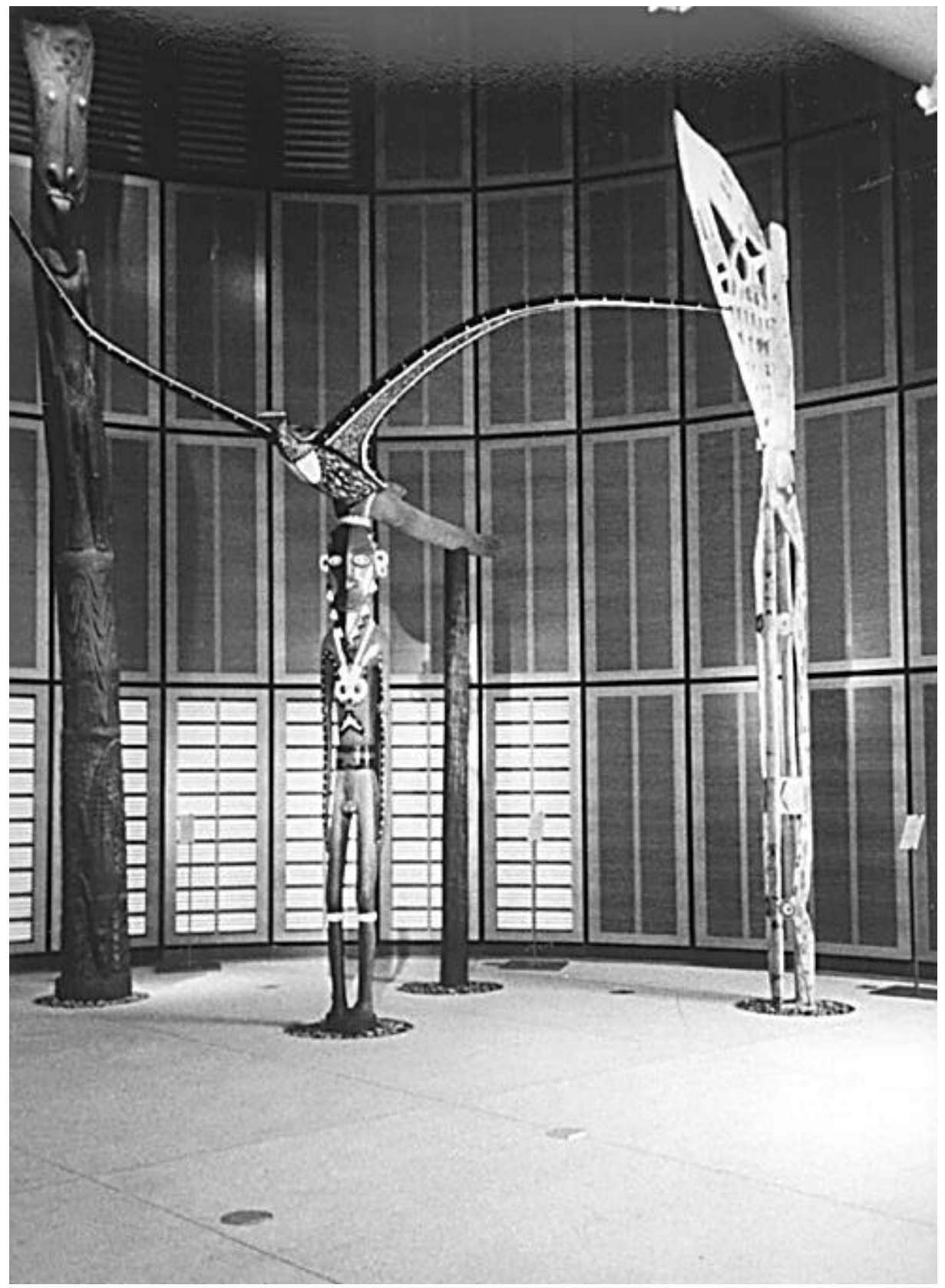

Figure 7. Jinu, sculptures (from left to right): Nawakumban, by David Yamanapi and Yarume Mambegiawai (Middle Sepik, Papua New Guinea); Nambal, by Bodoin Malres (Vao, off Malakula, Vanuatu); M'bitiro, by unnamed carvers (Mimika, West Papua). (Margaret Jolly) 
Vao in Vanuatu, from Aotearoa New Zealand, and from Australia (figure 7). These collectively embody the presence of ancestors, the bond between dead and living, and the connections between these several peoples and places. The Bangarra Theatre company of Aboriginal and Torres Strait Islanders from Australia worked with the Kanak dance group We Ce Ca. Bangarra choreographer Raymond Blanco thought that not being able to talk a common language of voice meant they got closer to the shared language of the body and the essence of indigenous spirituality (Ngan Jila I998). The works by resident visual artists similarly stressed not just the roots of their place but the routes that had brought them together for this collective creation. The French commissioned new art works not just from

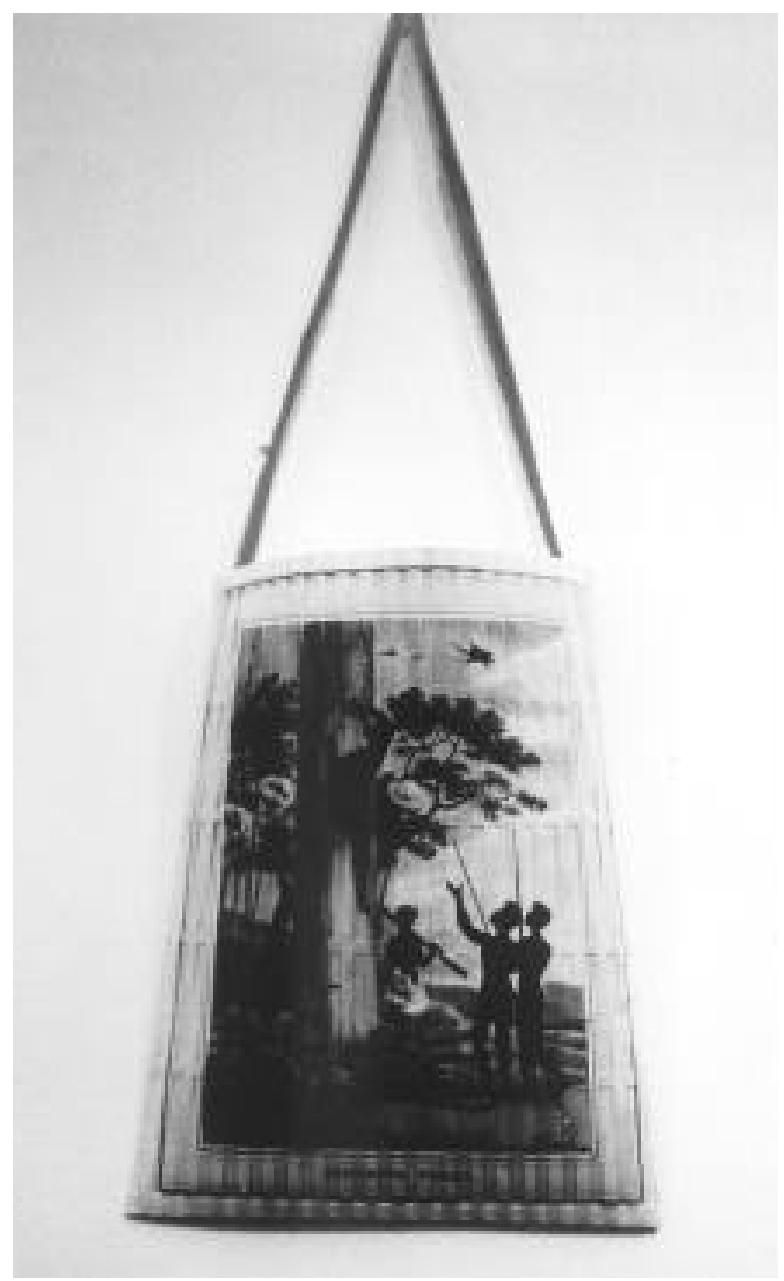

FIGURE 8. Bag woven from photographic reproduction of colonial painting of Australian Aborigines, by Fiona MacDonald, displayed at Mori Gallery Fisi exhibition during Pacific Wave Festival of Contemporary PacificArts,Sydney, November 1998. (Margaret Jolly) 
Kanak artists but from fifteen artists from across the Pacific and Australia who were flown to Noumea, fed, housed, and created art at French government expense. They made good choices.

From Australia came four gifted artists-the Aboriginal painters Judy Watson and Gordon Hookey, Ellen José from the Torres Strait, and Fiona MacDonald, a white Australian. Judy Watson painted Yam, another exquisite abstract canvas evoking the connection of ground and body through swirling confluences of ocher and indigo, with a delicate white tracery above suggesting the shape of a yam. MacDonald cut and wove copies of early photographs of New Caledonia and Kanak into baskets of distorted and reappropriated images (a technique she also deploys with earlier colonial art and photography in Australia to superb effect; figure 8).

Brett Grahame, a $\mathrm{M}$ ori sculptor, brought his beautiful, sardonic stone troika-Three Standing Stones or Melanesia, Polynesia, Micronesia (figure 9), ${ }^{29}$ and a superb sweep of wood, Kahakura. This represented both a rainbow and thus hope for the future and the red cloak of high-ranking $\mathrm{M}$ ori. It was dedicated to the memory of Rangi Mari Ite "the matriarch" of $\mathrm{M}$ ori weavers. Tina Wirihana plaited fine baskets from pandanus and coconut fibers as well as the flax fibers more familiar to her hands. She worked with Eric Natuoivi, a potter from Vanuatu, as he finished his small ceramic waka (canoe), their hands intertwining in shared plaiting of its miniature sinnet lashings. As Brett Grahame expressed it, the weaving and giving of fibers - mats, baskets, cloaks - evinces the uniting of people, communities, and families. Meanwhile, a more martial sense of connection was mobilized by John Wayne from the western Solomons, who carved a gigantic war canoe, similar to those of the late-nineteenth century that carried fifty or sixty warriors. He stressed that prior to conversion to Christianity, ancestral gods were carved holding the shrunken head of a war victim, but that this was replaced by a bird, embodying peace. He invited both participating artists and audience to join him in his war canoe and the big war canoe of cultural connection: the Jean-Marie Tjibaou Cultural Centre. Ellen José from the Torres Strait presented a rather more pessimistic reflection on the "coming of the light" in her own islands. Her installation of dour Mother Hubbard dresses, hung on lifeless black shop dummies, signaled for her the oppression of women that Christianity brought, an oppression still palpable for her in the dresses worn by many Kanak women who came to visit Ngan Jila.

Michel Tuffery's art projected a rather more light-hearted critique. $\mathrm{He}$ came from Aotearoa New Zealand with a mobile cow (or was it a bull?) 
with a huge rump and flashing eyes. Like its more immobile counterpart in Te Papa it was fashioned from Ox and Palm corned-beef cans and, declared Michel, designed not just to delight the kids but to inspire them not to trash the planet. While in residence, Tuffery crafted some superb iron skeletons of fish belching fire on the sand and floating on the edge of the lagoon around the promontory. Virginia King, another New Zealand sculptor, also used the ocean to float her "Reflections" a circle of wooden rods and blackened floats, suggestive of a flower, or a large sea anemone. The rods, lashed together in a circle, were for her like "the pulling together of the people, the pulling together of the artists," the flowering of the opening events. The wooden cedar rods had been disemboweled from the belly of an old organ, and she designed their acoustic play like watery wind chimes and their visual play in concert with the shadows of the red ribs of the building in the water. On each wooden rod was punched the words of Octavia Paz: "We must dream backwards to the source, we must row back up the centuries." Reflections on past cultural misunderstandings were for her crucial to creative communion in the present.

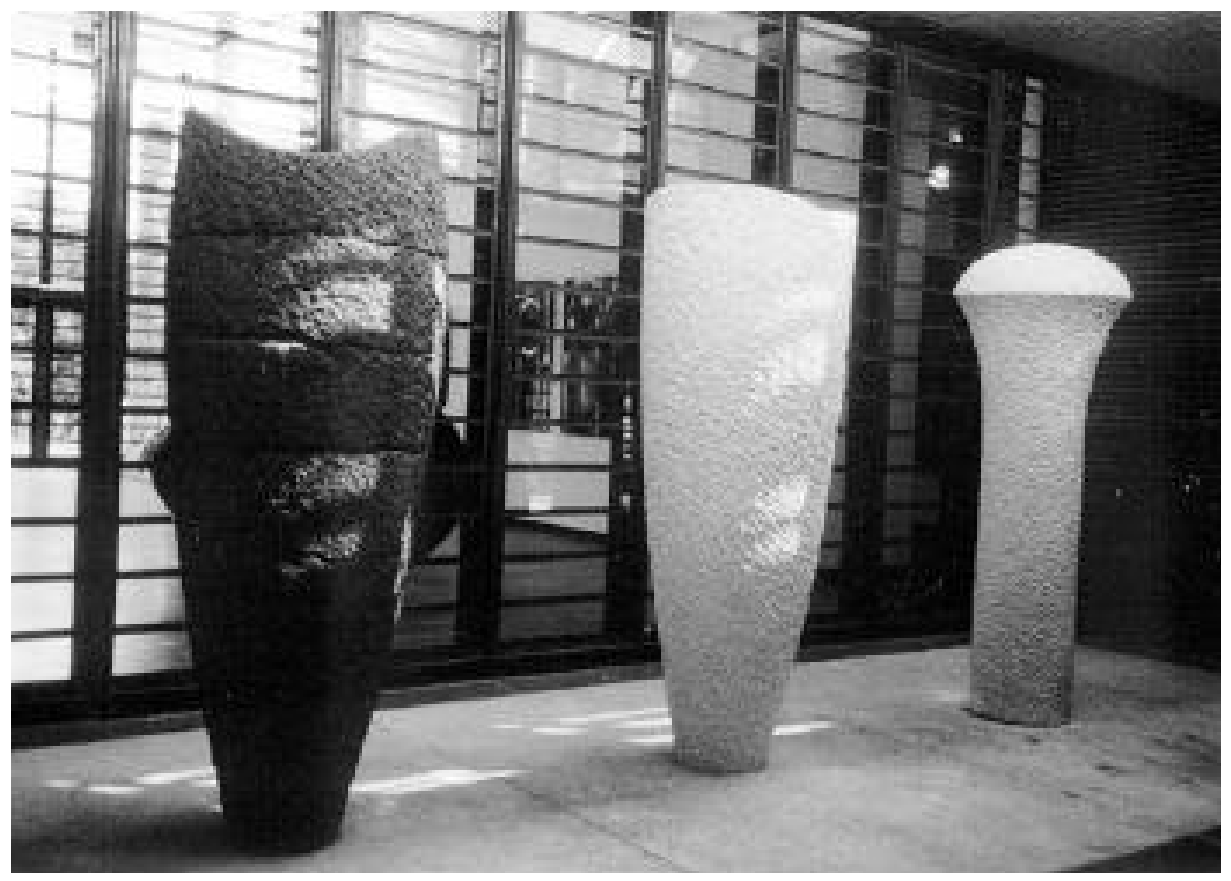

Figure 9. Three Standing Stones or Melanesia, Polynesia, Micronesia, by Brett Grahame. (Margaret Jolly) 
Clearly then, this is not just a center to celebrate indigenous culture in the nation of New Caledonia but across Oceania. Yvette Bouquet, the celebrated Kanak painter, expressed it poignantly "Kanak culture was trapped in French culture for a long time. We need you, we need these meetings." And as Emmanuel Kasarhérou, the cultural director, later remarked, he wanted to burst the bubble that separated the French from the rest of the Pacific. ${ }^{30}$ That bubble was burst. But the sheer beauty and wealth of this "House of Riches" also threatens to drown similar efforts in the poorer independent states of the southwest Pacific-such as the National Museum in Vanuatu or the new Oceania Centre for Arts and Culture at the University of the South Pacific in Suva. Moreover, although delighted by their experience of Noumea and the largesse of French support, several visiting artists also expressed some concern about how far the center could compensate for the horrors of the colonial past and the terrible consequences of nuclear testing, only recently suspended. Some were angry and embarrassed to hear that some Kanak could not, after the free period of the opening celebrations, afford the entry fee. ${ }^{31}$ Some were troubled about their complicity in attempts to remake France's Oceanic image.

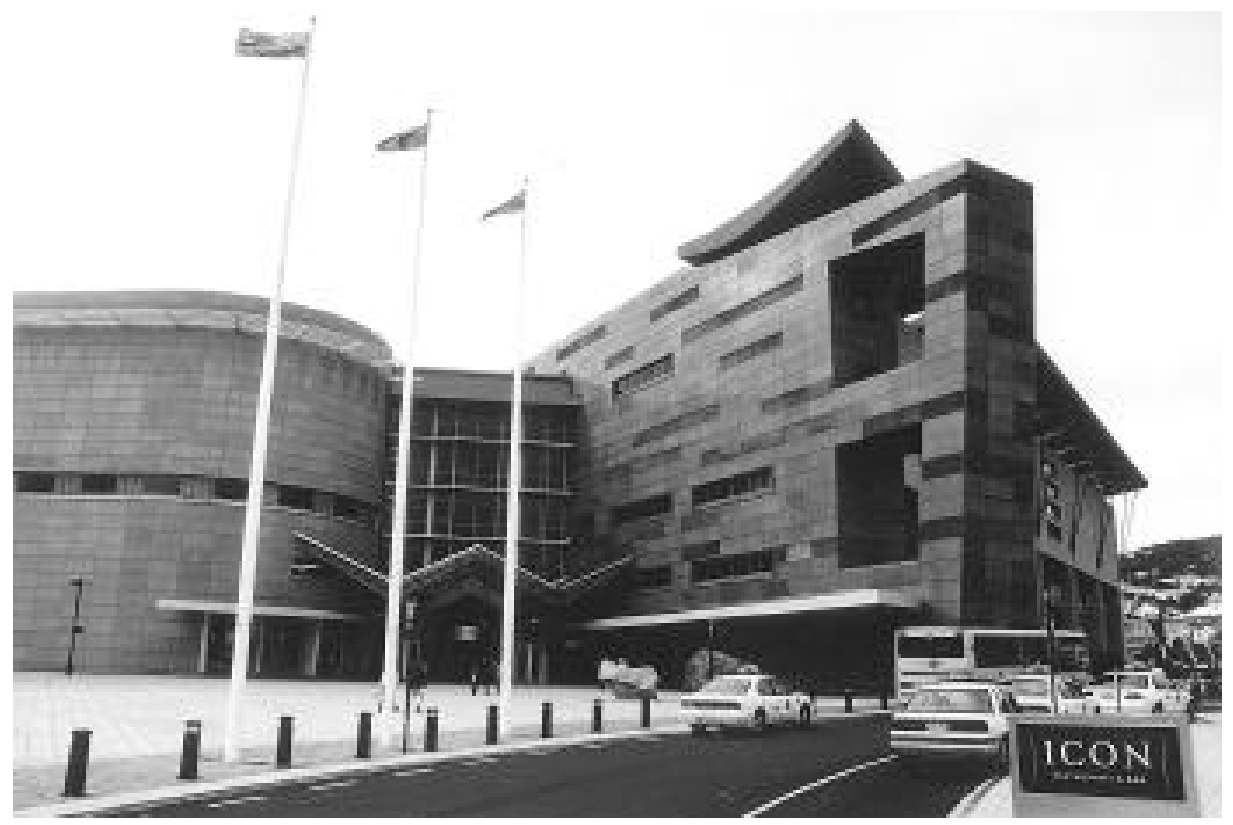

Figure io. Te Papa, Wellington, exterior view facing Cable Street. (Margaret Jolly) 
Wellington: Te Papa, the National Museum of New Zealand

The National Museum in Wellington, Te Papa, ${ }^{32}$ has proved contentious in other ways. Unlike Renzo Piano's celebrated structures, this building on a superb waterfront site in windy Wellington is not universally popular, occasioning a mixed reception from local and overseas commentators, "it is alternately considered a triumph of design and an architectural turkey; a powerful statement of New Zealand's cultural identity and a discordant mish-mash of competing interests" (Kent I998, 84). To my eye, the combination of blond and grey façade, of curves, jutting angles, and waving roofline is too heterogenous, and is further disturbed by the bright blocks of colored glass on the streetscape (figure 10). ${ }^{33}$ The building works better on the harbor side and on the inside, where the vistas of the ocean come forward into the space of galleries, the sense of wind and water is beautifully trapped in pools and flax plantings, and where the marae ( $\mathrm{M}$ ori meeting place) opens out from Bob Jahnke's superb stained-glass doors (figure II).

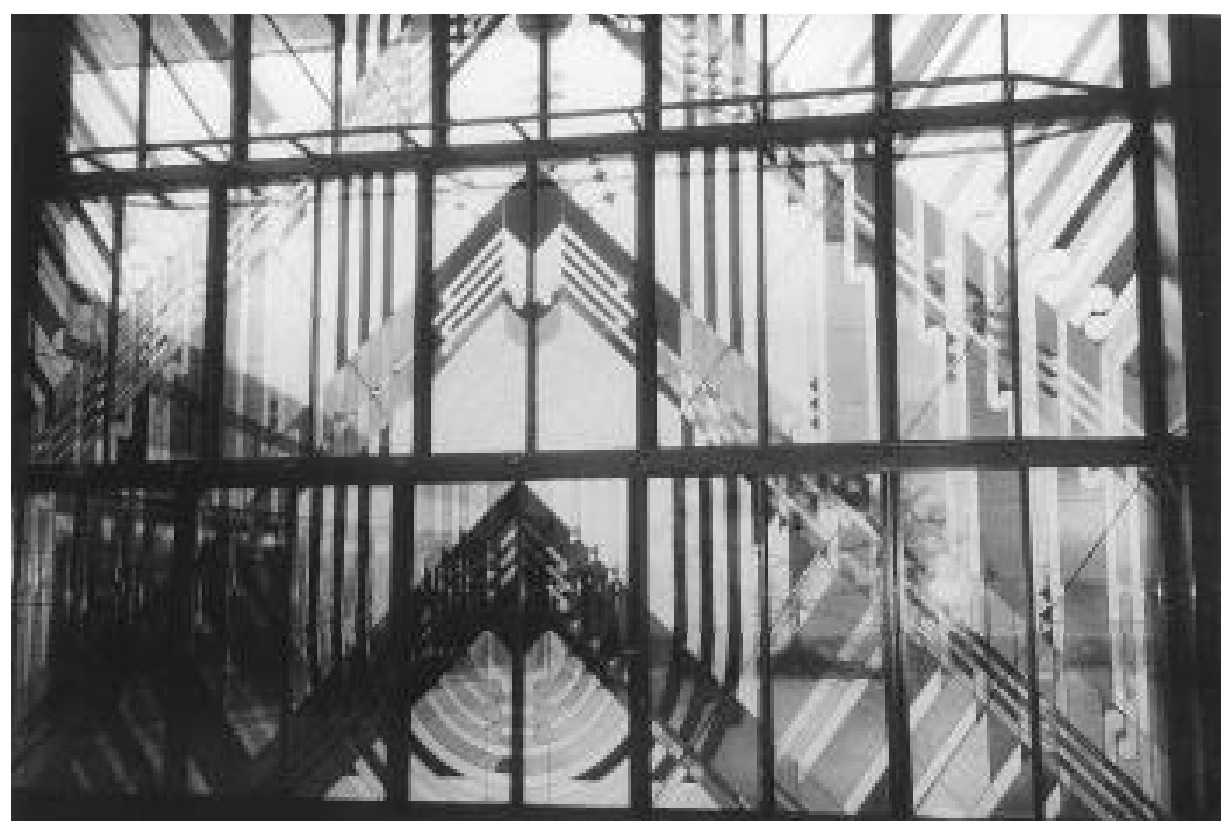

Figure i i. Stained glass door on marae, by Bob Jahnke, Te Papa, Wellington. (Margaret Jolly) 
The architects' brief was a difficult one-to construct on reclaimed land, close to a major geological fault line, a building that would last for one hundred and fifty years. It would be both a museum and an art gallery and "express the bicultural nature of the country and the contributions made to it by people of diverse origins." The original competition concept, which won the contract for Jasmax architects and Ivan Mercep, was successively transformed in response to changing demands of construction, curatorial concepts, and the client's priorities. The seismic peril of the waterfront site, its marginal "bearing quality," was solved by compacting the ground and then floating the building on a huge raft of concrete beams and pads, on top of which I 50 lead and rubber shock absorbers carry the building itself. Cladding panels are suspended on stainless steel hangers that allow independent movement, and window frames are designed to accommodate large movements. New Zealand materials were chosen as much as possible - the external cladding is oatmeal-colored dolomite from Nelson, while the sweep of the diagonal wall that traces the fault line is black basalt from Auckland. The superb internal wood panels are veneers of New Zealand timbers-mataī, rewarewa, and tawa-and the ceiling battens macrocarpa. But the glass of the large external windows was imported from the United States, and the floor in the public circulation areas is granite from India.

The seismic instability of the site is reflected in the fault lines of the architecture and the shifting ground of its curatorial concepts. In the huge display space of ten thousand square meters, exhibitions cover natural environment, social history, $\mathrm{M}$ ori culture, and art. The lower floors focus on the natural environment-energetically evoked with dioramas, virtual bungee jumps and windsurfing, and computer-simulated earthquakeswhile a walk across the swing bridge of "Bush City" outside traverses the diversity of wetlands, rainforest, and volcanic landscapes. ${ }^{34}$ The cultural environment, no less varied and shifting, is the focus of several galleries on the upper floors. Here fault lines emerge between the museum's bicultural and multicultural agendas and between Te Papa's dual purpose as a museum and art gallery. The architectural designs clearly encode the predominant value of biculturalism in the relation of indigenous $\mathrm{M}$ ori and settler Pakeha, by evoking both the differences between them in their orientation to the land and architectural form and their common ground.

The $\mathrm{M}$ ori exhibition area and the Marae were oriented overlooking the sea toward the rising sun and the direction of the most openness (the Harbor and distant Tararuas), which respects the siting traditions frequently followed in the location of iwi marae throughout New Zealand. The Pakeha section, con- 
taining the Art, History and Natural Environment galleries were housed in a section of building which responds to the grid-like patterns of city streets, which is typical of the way Europeans settled the new colony, and have tended to do since the Romans expanded across Europe. Between the two was a large ceremonial concourse, a glazed verandah five storeys high under a dramatic floating roof, which gave the galleries their separate identities whilst also offering a sense of a meeting space between. (Bossley 1998, 9)

The sense of difference and connection is further expressed in the central space, a wedge "expressing the idea 'to cleave', which means both 'to split' and 'to adhere'." 35 In this bridging place, the most powerful icon of biculturalism is celebrated-the Treaty of Waitangi-signed by $t$ ngata whenua ( $\mathrm{M}$ ori) and $t$ ngata tiriti (Pakeha) in I 840 . The original lies safely in the National Archives. Here is hung a simulacrum of this ravaged parchment, suspended in glass, etched with replicas of the original signatures. On either side the words of the treaty are inscribed in panels in $\mathrm{M}$ ori and English. Steel columns cluster around like sentinels, emitting muted voices that debate the significance of the treaty, past and present, in relation to land, citizenship, and governance.

On either side of this shared space, $\mathrm{M}$ ori and Pakeha halls diverge. You enter the $\mathrm{M}$ ori halls from the entrance up a long, sloping corridor where Jacqueline Fraser has created a delicate whakapapa or genealogy, not with strings of pandanus but electrical wire. This is Te Ara a Hine (the pathway of women). It leads up to the marae and Cliff Whiting's celebrated if controversial wharenui (meetinghouse), with its lurid embodiments of the ancestors in psychedelic yellows, blues, and purples. This is a living marae, which can be used by $\mathrm{M}$ ori groups for meetings and cultural events and even for sleeping over. It opens out onto the harbor, through Bob Jahnke's stained-glass doors onto a windswept verandah where more Cliff Whiting sculptures flank the entrance. The original design had the marae in a more customary locale on the ground floor and projected a link to the sea where canoes could be hauled up. According to Paul Tapsell (personal communication July I998) many $\mathrm{M}$ ori are unhappy that the marae is upstairs and that such a tapu place is too proximate to the posh cafes and the toilets. Some of this criticism seems to have been muted after the success of the inaugural ceremony, when Jahnke's huge stained-glass doors (representing Ranginui, the sky father) were opened up and $\mathrm{M}$ ori elders arrived on the marae in the first light of dawn. The spirit of biculturalism was apparent in this opening as in the protracted process of consultation with $\mathrm{M}$ ori iwi (tribes) and the inclusion of many $M$ ori on the curatorial and management staff. Although 


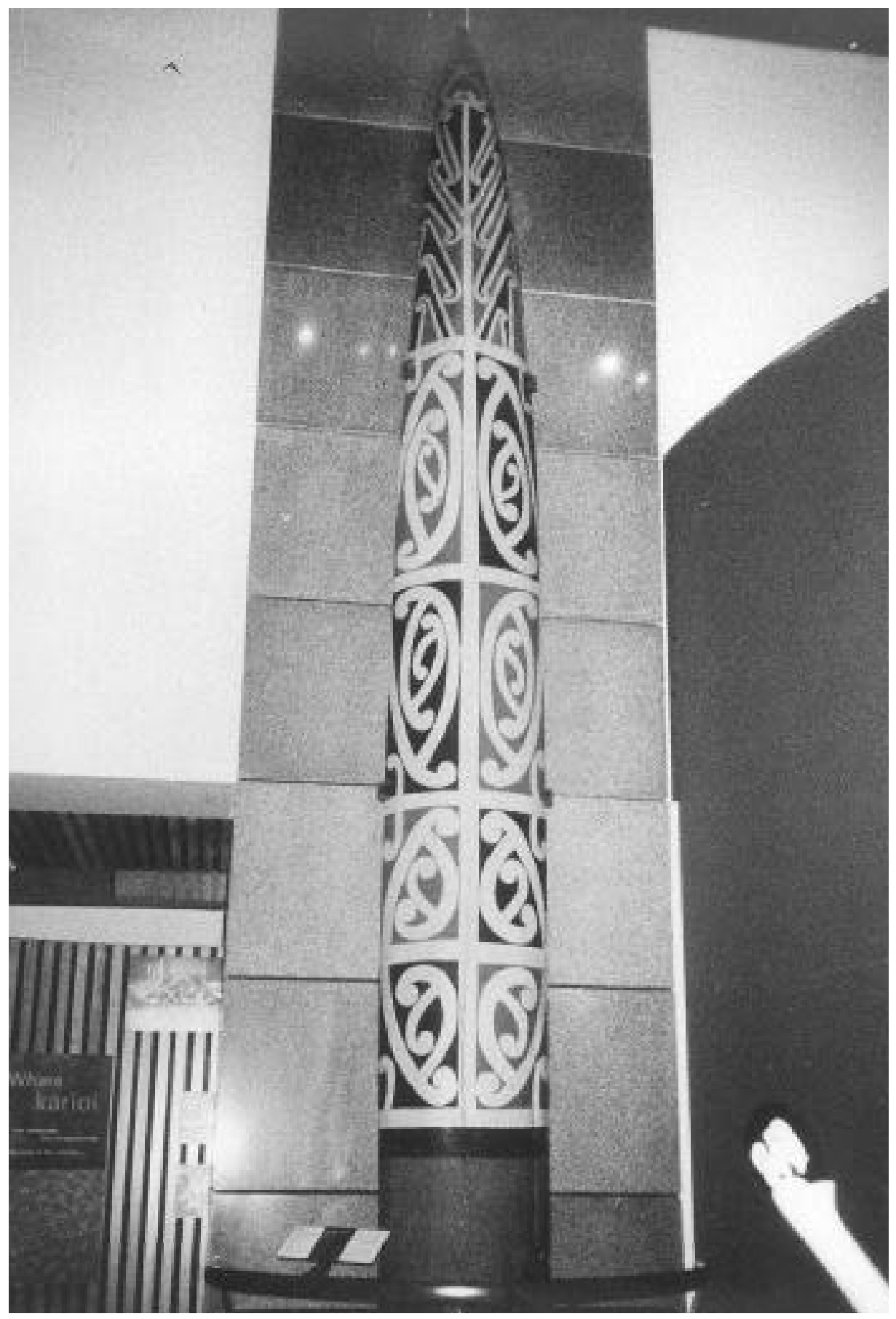

FIGURE I 2. Waka - a waka whakamaumaharatanga, a memorial marking the spiritual journey of the dead to Hawaiki, carved by Neke Kapua and his sons Tene and Eramiha of Ngati Tarawhai, for Christchurch Exhibition 1906. (Margaret Jolly) 
Cheryll Southeran is chief excecutive of the corporate structure, Cliff Whiting, the $\mathrm{M}$ ori concept creator, designer, and chief carver of the wharenui, has equal standing with her in cultural management.

The marae leads into the $\mathrm{M}$ ori halls, which with their deep dark vaults and dim lights create a strong sense of seriousness, calm, and spirituality. Massive sculptures of wood and stone, large houses, and huge canoes dwarf the human subject (figure I 2). Connections to the majesty of Hawaiian hierarchy are summoned by the display of the superb feathered cloak given to Cook. But a countervailing sense of intimacy and interaction is created by a string of musical instruments one can play on tape and the delicious sensation of seeing greenstone being formed and polished with water. One object in the $\mathrm{M}$ ori halls I found breathtaking in its brilliant simplicity was a large lump, an island of greenstone, inside a font of water shaped like a waka (canoe). For me this embodied that very conjunction of ground and ocean, island and canoe, I have tried to highlight in this paper (figure I3).

The $\mathrm{M}$ ori exhibits - both contemporary and ancient creations-evince a deep spirituality and invite quiet contemplation in the viewer. The over-

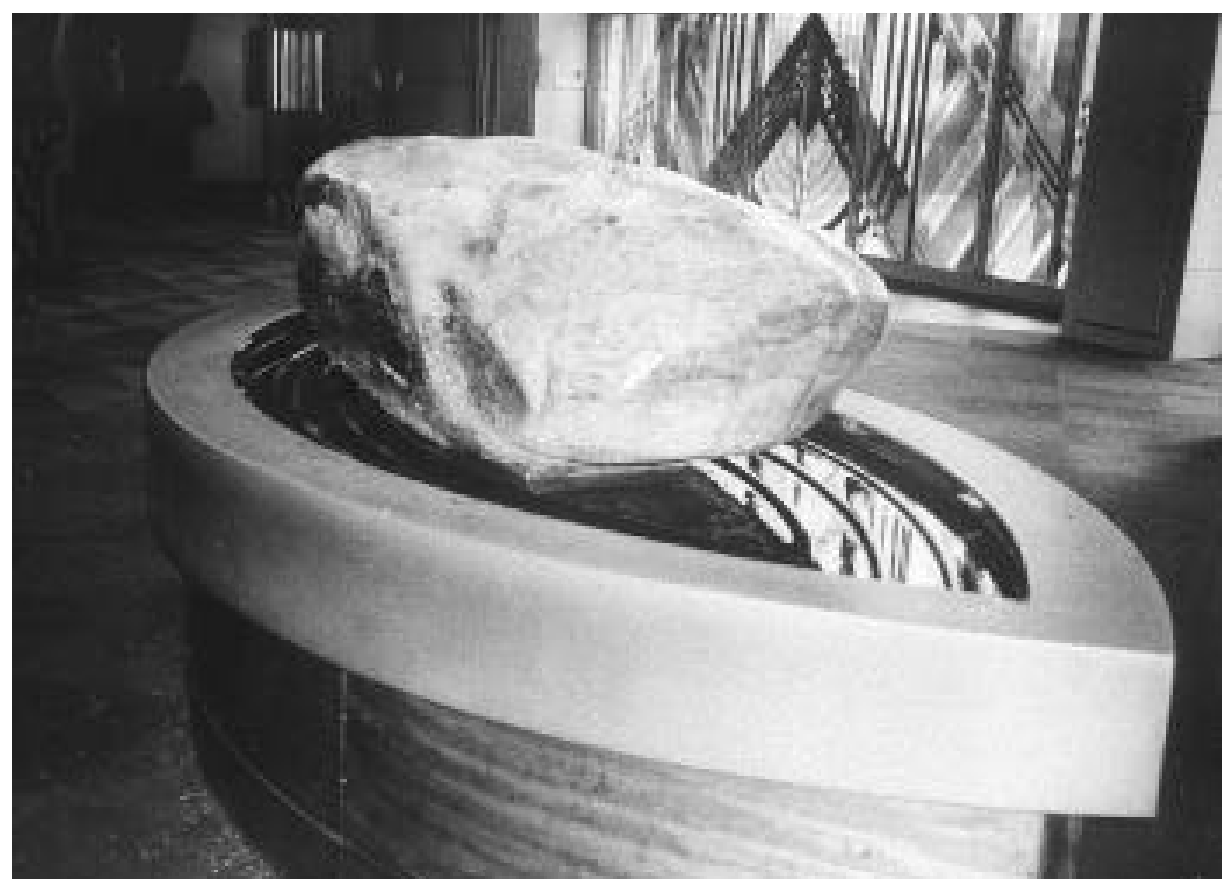

FiguRE I 3. Greenstone island mounted in font of water shaped like a canoe, Te Papa, Wellington. (Margaret Jolly) 
all texture of the $\mathrm{M}$ ori halls is very different from those that display Pakeha, Islander, and Asian history. Despite the strong bicultural message, and the sense of parity and even partnership created by the juxtaposition of the Treaty of Waitangi in $M$ ori and English, the halls devoted to the European heritage often display a mock imperial pomp and an attitude to the past that lurches between guilt and laughter. The messages of past public health campaigns are particular targets of mirth (figure I4). More serious displays of the history of migration in the installation "Passports" bring the stories of immigrants alive, not just through identity papers and oral histories but through a replica of a steerage berth. Another popular exhibit devoted to the history of sheep, invites the visitor to have a go at shearing, while "Golden Days" combines the detritus of domestic memorabilia-toys, appliances, cricket balls, photographs-with the haunting sounds of an old pianola.

Although this evokes nostalgia for many Kiwi visitors, there seems to

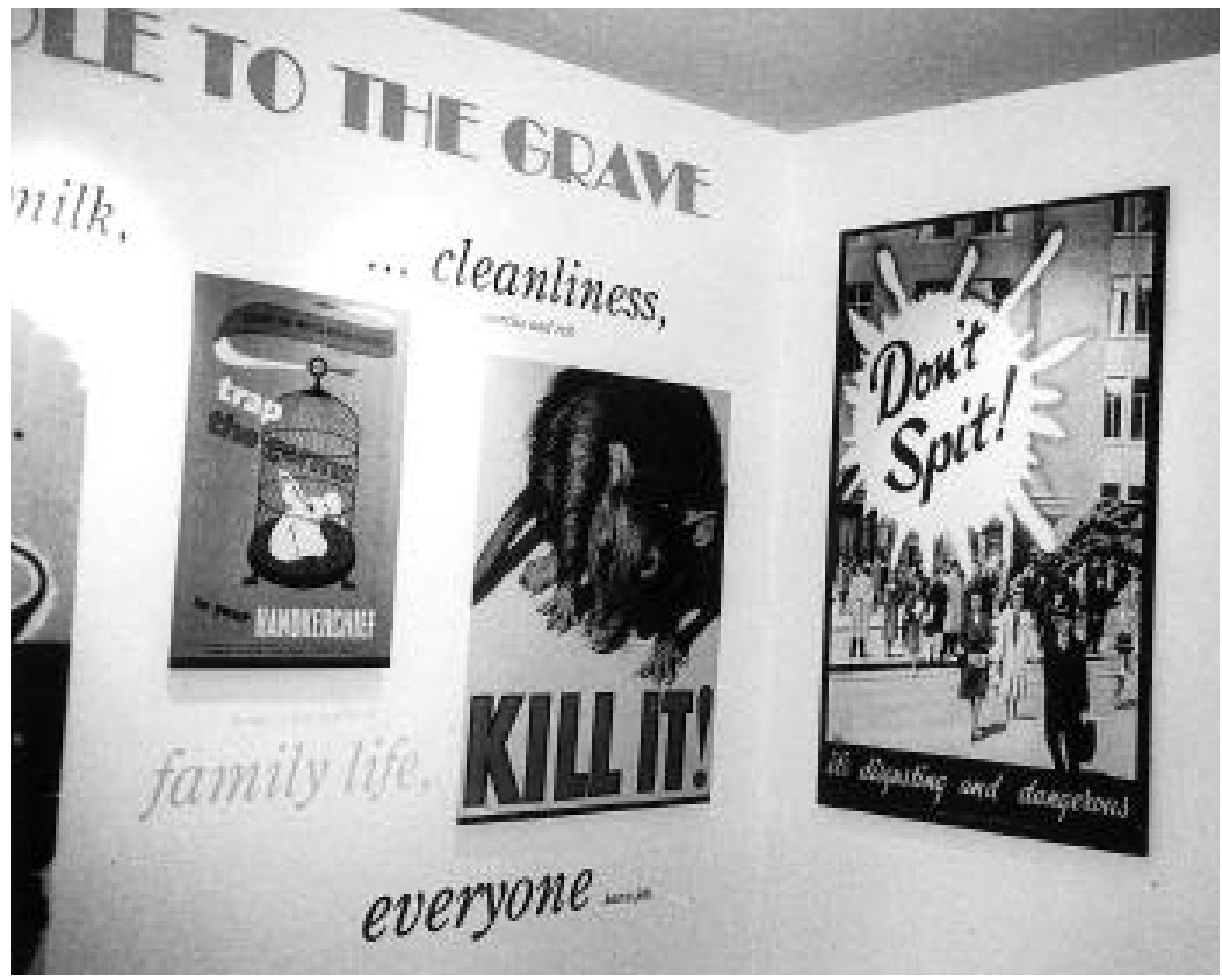

Figure I4. Posters from past public health campaigns, Te Papa, Wellington. (Margaret Jolly) 
be a scrupulous avoidance of the sacred in Pakeha cultural history. Any sanctity imputed to the most famous works of Pakeha "art" is subverted. ${ }^{36}$ In the permanent exhibit designed by Ian Wedde, "Parade," Colin McCahon's Northland Panels of 1958 is hung alongside a Kelvinator Foodarama 7 refrigerator of 1959. Famous art works from the first days of the colony to the present are interpersed with costumes, furniture, white goods, motor scooters, and America's Cup memorabilia. This motivated mix of art and the artifacts of popular culture is accompanied by a zesty even cavalier address to the audience, in captions like "Is it art?" "No great shakes as a painting." Some offended art critics lamented this dedication to making Pakeha art profane. Said one, "Maori taonga (sacred treasures) . . . elsewhere in the museum have not been subjected to the same treatment" (Kent I998, 85). Simon Rees noted a disproportionate deference to $\mathrm{M}$ ori artifacts as against those of Pakeha (1998). Where is the reconstructed early church, he asked?

Like the display of high "art," the representation of the Pacific Islander experience has proved problematic. Many Islanders, including some involved in the curatorial consultations, are unhappy with the small scale of the exhibits (279 square meters in Mana Pasifika and Ior square meters in PlaNet Pasifika). There were earlier plans for a large canoe court of about I,200 square meters downstairs ${ }^{37}$-a space that would have connected to the ocean beyond and have highlighted the deep cultural connections of migrant Samoans, Tongans, Niueans, and Cook Islanders with indigenous $\mathrm{M}$ ori (Williams I998, I7). As I have shown, the canoe and navigation have been a powerful means of imagining connection between Polynesian peoples past and present. The grandeur of this ancient cultural connection was foregone, and the space dedicated to an area for conventions or perhaps a millennium show that might last twenty years. Representations of the Islander experience have thus become not only more cramped in a smaller gallery space, but imaginatively limited by the parameters of the New Zealand nation. ${ }^{38}$

Still, within the limits of reduced space and budget, the Pacific curators have succeeded in giving a sense of the diversity and dynamism of island cultures. These halls highlight a display of daily life and costumes, past and present. Some commentators have lamented the radical juxtapositions: of the famous chief mourner's costume from Tahiti with a green lycra dress, or the proximity of a Niuean warrior costume and a contemporary Fijian army uniform. I rather relished such counterpoints. And the celebration of Islander achievements in New Zealand through the life histories of individual Samoans, Tongans, Niueans, and Cook Islanders has proved 
immensely popular with adults and children alike. But the celebration of modernity and of a "groovy" Islander style is dramatically at variance with the serious, spiritual tone of the $\mathrm{M}$ ori halls. Moreover, earlier and ongoing connections between $\mathrm{M}$ ori and other Islanders might have been represented in ways that were not, in the partisan views of some Te Papa defenders, dusty ethnographic anachronisms. ${ }^{39}$ The insistence on Pacific Island culture as it exists in New Zealand has suppressed these connections in favor of a bicultural focus, on the $\mathrm{M}$ ori-Pakeha relationship.

Te Papa is self-consciously a national museum. Said one press commentator, "A lot of what's on display may well be meaningless to people from overseas, but that's alright by me because it truly is Our Place" (Roger I999). It has been immensely popular-attracting I00,000 visitors in its first week, and I.3 million in its first eight months. It has continuing very high levels of patronage, especially from local Wellingtonians and from other parts of the country. ${ }^{40}$ Many visitors have returned several times, perhaps partly because there is no entry fee (although some virtual reality exhibits have charges). ${ }^{41}$ Te Papa clearly aspires to create a narrative of connection between the first people of the place, the $\mathrm{M}$ ori, the white settlers or Pakeha, and later migrants from the Pacific and to a much lesser extent, Asia. ${ }^{42}$ Unlike the new national museum in Port Vila, it embraces and juxtaposes earlier and contemporary arts, indigenous "artifacts," and introduced forms. Unlike that museum it has to deal with the continuing presence of a dominant white majority in a settler colony. And yet, unlike Noumea's Ngan Jila, Te Papa is not a museum that so much affirms indigenous culture and its regional connections as tries (and in my view fails) to negotiate the complexities between the biculturalism of $M$ ori and Pakeha and the multiculturalism appropriate to later migrants from other parts of Europe, the Pacific, and Asia.

The dominant national ideology of Aotearoa New Zealand articulates a distinctive relation between indigenes and the most recent wave of immigrants, who are predominantly Islanders - from Tonga, S moa, the Cook Islands, and Niue, in particular. Despite the common complaint that Islander migrants are viewed by the state through a lens appropriate to $\mathrm{M}$ ori, and the tensions that have sometimes developed between $\mathrm{M}$ ori and Islander views and claims (as around Te Papa), there is still often a politics of precedence, whereby the multicultural claims of migrants must defer to the dominant bicultural logic of $\mathrm{M}$ ori and Pakeha, indigenous and white settler, $t$ ngata whenua and $t$ ngata tiriti (the people of the land and the people of the treaty). 


\section{Sydney: Pacific Wave}

And now back to Australia. The Australian state, though similar to New Zealand in being a British settler colony with an indigenous population demanding their rights of historical redress, reconciliation, and compensation, stresses multiculturalism rather than biculturalism (Pettman I995). Unlike Aotearoa New Zealand, Australia has, since World War Two had a huge and diverse stream of migrants from Europe (especially Britain, Italy, Greece, Germany, and Holland), the Middle East, Indochina, South and Southeast Asia, and Latin America. A very small percentage of recent migrants is from the Pacific, and many of these are step migrants from Aotearoa New Zealand. Unlike Australia's indigenous population, migrants are often celebrated as a benign inclusion or incorporation in the Australian body politic (see Jolly I999a; Reardon-Finney 1999).

Indigenous identities have also been used to legitimize Australian nationalism, but have rarely been so available for such a benign celebration of difference. Rather the politics of this difference has typically been one of disruption and conflict. When Australia celebrated its bicentenary in I988, ethnic communities were, for the most part, incorporated in its several spectacles. But many Aboriginal people either boycotted the event or held protests and laments at what for them was an anniversary of two hundred years of white occupation, and declared 1988 a National Year of Mourning. Difference is by this model inherently conflictual, born of a violent colonial struggle, the near genocide of people, and the occupation of their land, facts that have to be admitted and apologized for before they can be redressed. The key concept of "reconciliation" was deployed by the Labour government led by Paul Keating. It was subsequently attacked by the incoming conservative Prime Minister John Howard, who in 1998 equated understanding of Australia's past with a "guilt industry" or "black-armband history" and in 2000 queried the reality of "the stolen generation," those children removed from their Aboriginal families into white foster homes and church and state institutions. Earlier, even more vociferous attacks came from Queensland Member of Parliament Pauline Hanson, who wanted not just to stop Asian immigration and Australia's overseas aid program, but to halt the allegedly special treatment of, and fiscal squandering on, Aborigines. Still, as I write, Howard has refused to say sorry or to participate in the mass walk across the Sydney Harbour Bridge in May 2000, which was to be the culmination of a ten-year journey of national healing. (He went to the football in Canberra instead. It 
snowed bitterly.) Some Aboriginal groups threatened to disrupt the Olympic Games in Sydney in protest. Although indigenous and migrant elements figured largely in the opening ceremony of the games, they were preceded by a cavalry of white stockmen. The articulation of indigeneity and diaspora is rather differently hooked up in Australia.

Here there is no comparable art event associated with the opening of a national museum, since Australia did not have one at the time of writing. ${ }^{43}$ Rather, I consider a different genre of aesthetic performance, the most recent Pacific Wave festival in Sydney in November 1998, which included many exhibitions and performances throughout public and commercial gallery spaces and performance venues in inner and outer Sydney. The Pacific Sisters-a collective of young fashion designers, artists, and musicians from Aotearoa New Zealand performed Tribe Vibe in the performance space in Redfern: street gear, live music, rapping, and video. George Telek, a Tolai musician from Papua New Guinea, teamed up with David Bridie, an Australian musician. Lisa Reahana installed her "video weav-

FIGURE I 5 . Shell necklace, by Sofia Tekela, displayed at Mori Gallery Fisi exhibition during Pacific Wave Festival, Sydney, November 1998. (Margaret Jolly)

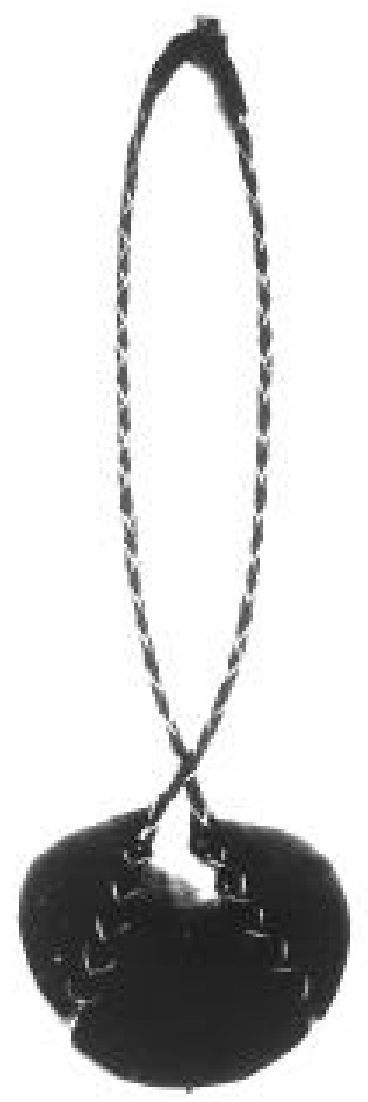


ings" in the showcases of the old Mark Foys department store in central Sydney. At the Bondi Pavilion there were exhibitions of marine art to celebrate the year of the ocean; Aboriginal art from Cape York and the Gulf of Carpentaria; a forum with Dennis O'Rourke about European documentary film in Papua New Guinea; and a Big Sunday dedicated to Aboriginal and Pacific dance and music, arts and crafts, and workshops for the kids. At the Mori Gallery, there was Fisi: The Blossoming of the Waves, which displayed superb creations by Australian and New Zealand artists (figures I5, I6).

But here I focus on two simultaneous exhibitions in Casula Powerhouse - a capacious even cavernous space, beside the railway tracks in outer western Sydney-where great efforts have been made to bring contemporary art exhibitions to the white working class and migrant communities of its proximate suburbs. Downstairs hung the stunning fibrous forms of women's art, woven and plaited by both Pacific and Aboriginal women - baskets and bowls woven by Ahitautama Makaea Cross from Niue

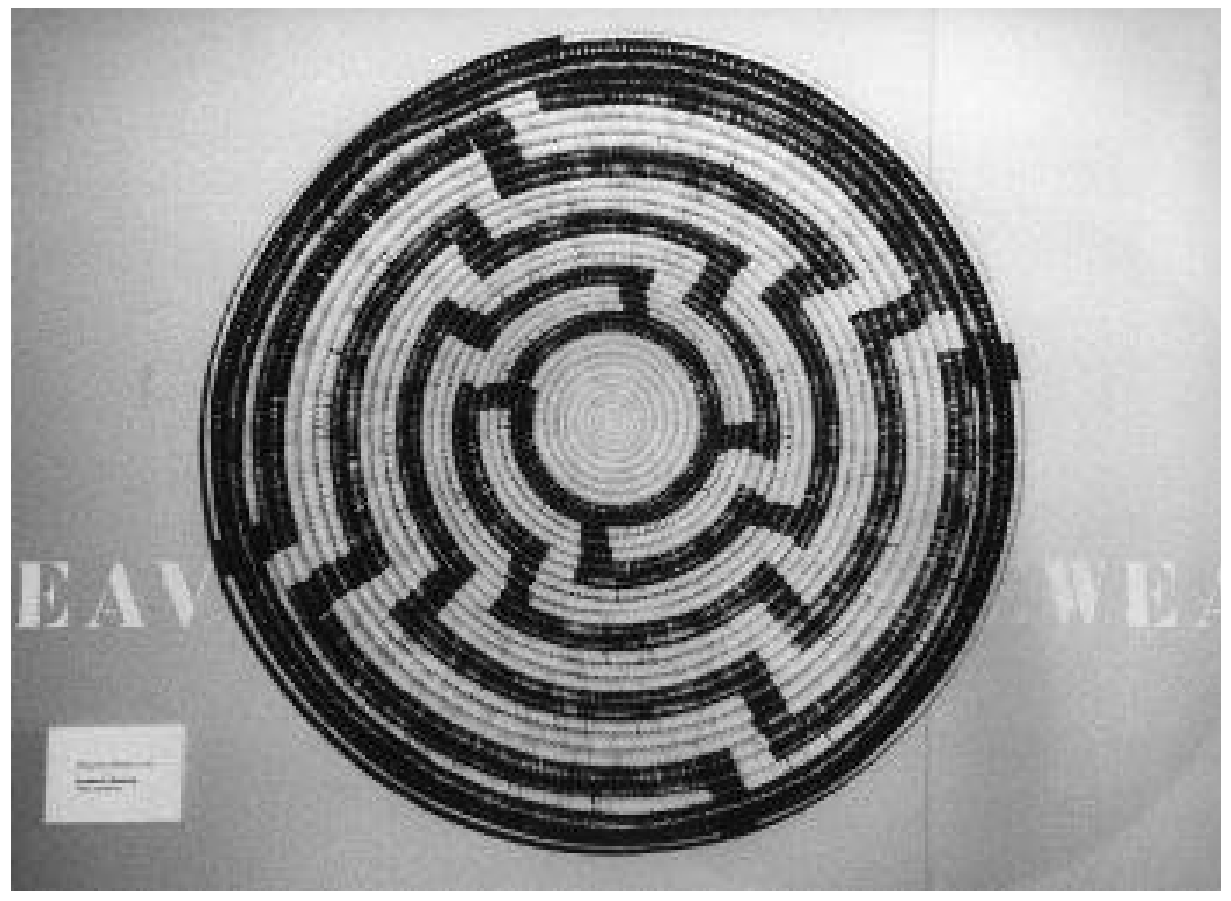

Figure i6. Basket, by Ahitautama Makaea Cross, displayed at Casula Powerhouse Weave exhibition during Pacific Wave Festival, Sydney, November 1998. (Courtesy of Casula Powerhouse Arts Centre, Casula, Sydney, Nsw. Margaret Jolly photo) 
were next to a fish trap by Yvonne Koolmatrie from the Riverland in South Australia (figure I7). There were soft skirts and caps from the Highlands of Papua New Guinea, fashioned from possum fur with subtle browns and ochers, the colors of the earth. Next to them, conceived and in part created by the same artist, Mary Siune Jack, there were bilums in the vibrant hues of chemical dyes and bras (baskit blong titi), which looked like bilums, made with the imported palette of red, black, and yellow, the colors of the flag of Papua New Guinea and fortuitously of Australian Aboriginal sovereignty (figure $\mathrm{I} 8$ ). With this deliciously creole costume, nationalist spirit was both declared and subtly subverted. Overall, this show, Weave, was a quiet but potent celebration of affinities between Aboriginal and Pacific women and of their common cultural survival.

Upstairs in the same venue was another rather different exhibition, Furious. Here, in vibrant oils, the Aboriginal artist Gordon Hookey attacked the virulence of Australian racism, assaulted John Howard (our prime minister) with barbs of wit and literal spears. He attacked Pauline

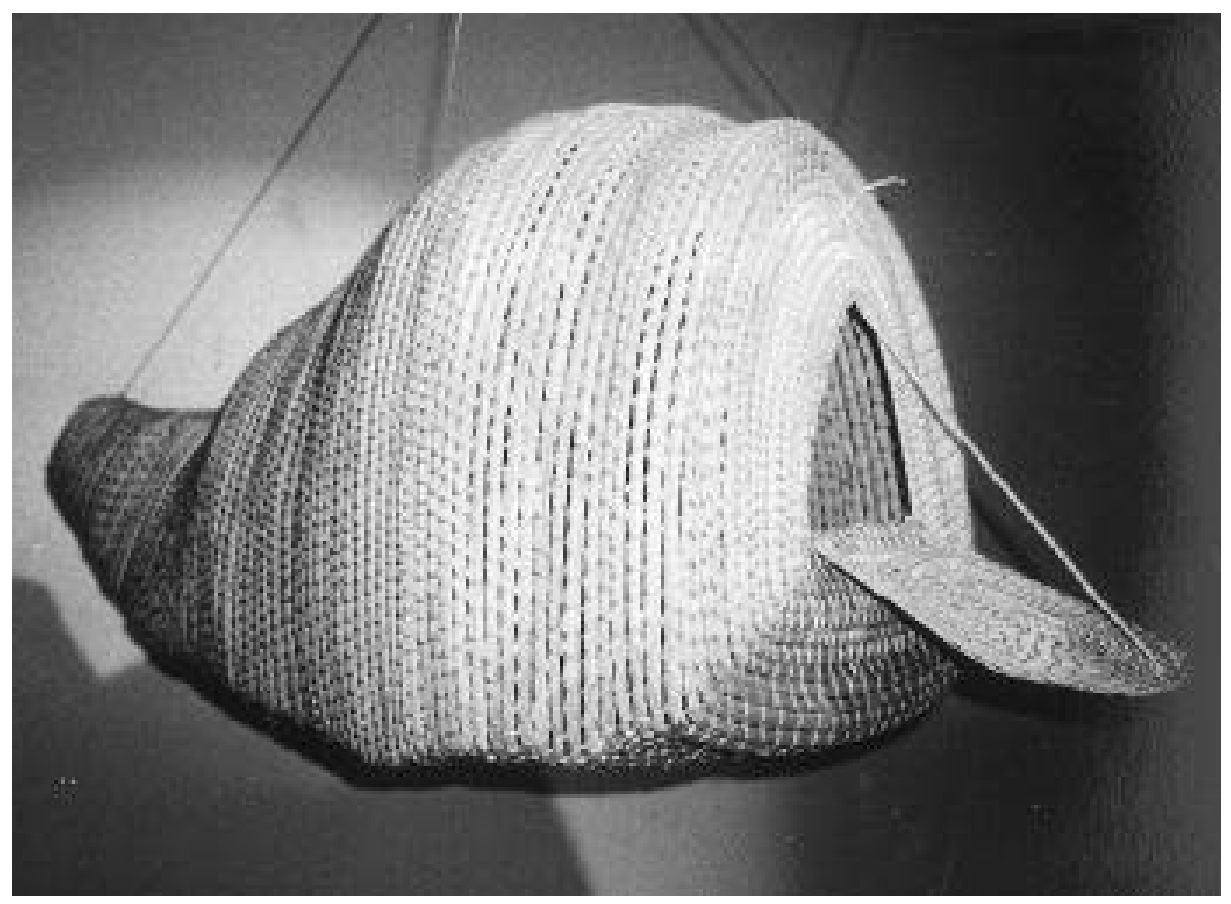

Figure I7. Fish trap, by Yvonne Koolmatrie, displayed at Casula Powerhouse Weave exhibition during Pacific Wave Festival, Sydney, November 1998. (Courtesy of Casula Powerhouse Arts Centre, Casula, Sydney, Nsw. Margaret Jolly photo) 


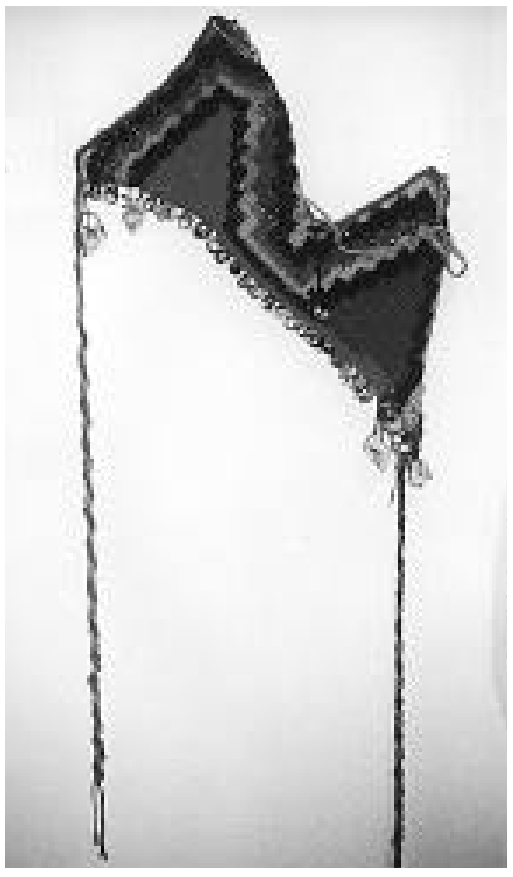

Figure I 8. Bilum brassiere, in colors of PapuaNew Guinea flag, by Mary Siune Jack. (Courtesy of Casula Powerhouse Arts Centre, Casula, Sydney, Nsw. Margaret Jolly photo)

\section{Below:}

Figure 19. Painting Payback Paintin', by Gordon Hookey, oil on canvas, I $72 \times 164 \mathrm{~cm}$. (Courtesy of Casula Powerhouse Arts Centre, Casula, Sydney, Nsw. Margaret Jolly photo)

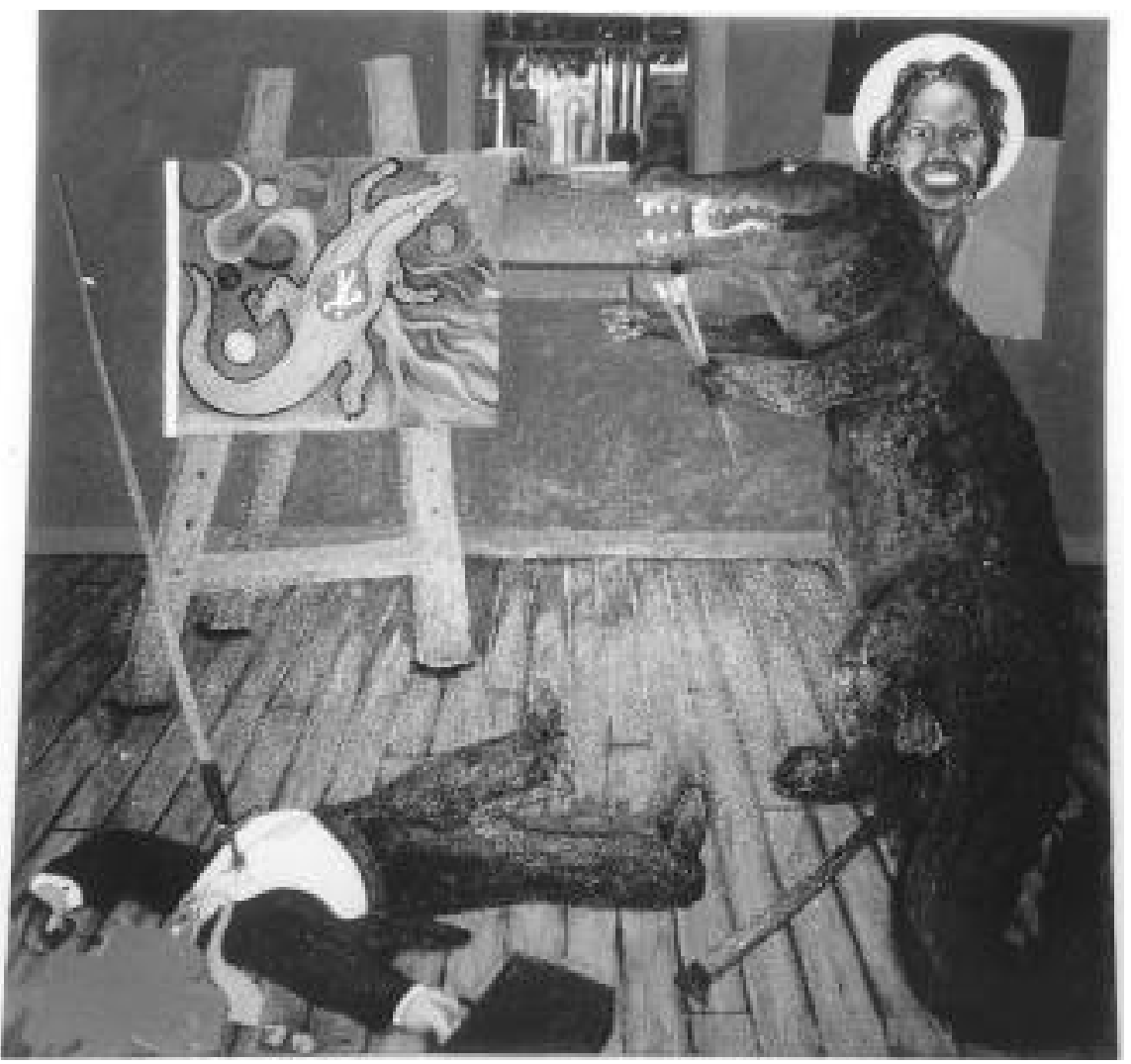


Hanson, the notorious One Nation, white power politician, by giving her a brick toilet replete with a swastika, toilet paper in the colors of the Aboriginal flag, and the gastronomic signs of the Asians she desired to send back home (figure I9). Next to Hookey hung the equally violent images of Andy Lelei, a Samoan artist from New Zealand, whose fury was directed elsewhere. His paintings mourned the tragedy of male suicide, deplored the horror of domestic violence in Islander families, and expressed rage, not just against hierarchy in the Samoan "community" but the hypocrisy he perceives in the Christian churches. One painting, whichbore the phrase "Samoan born ministers are wankers," so infuriated some Sydney Samo-

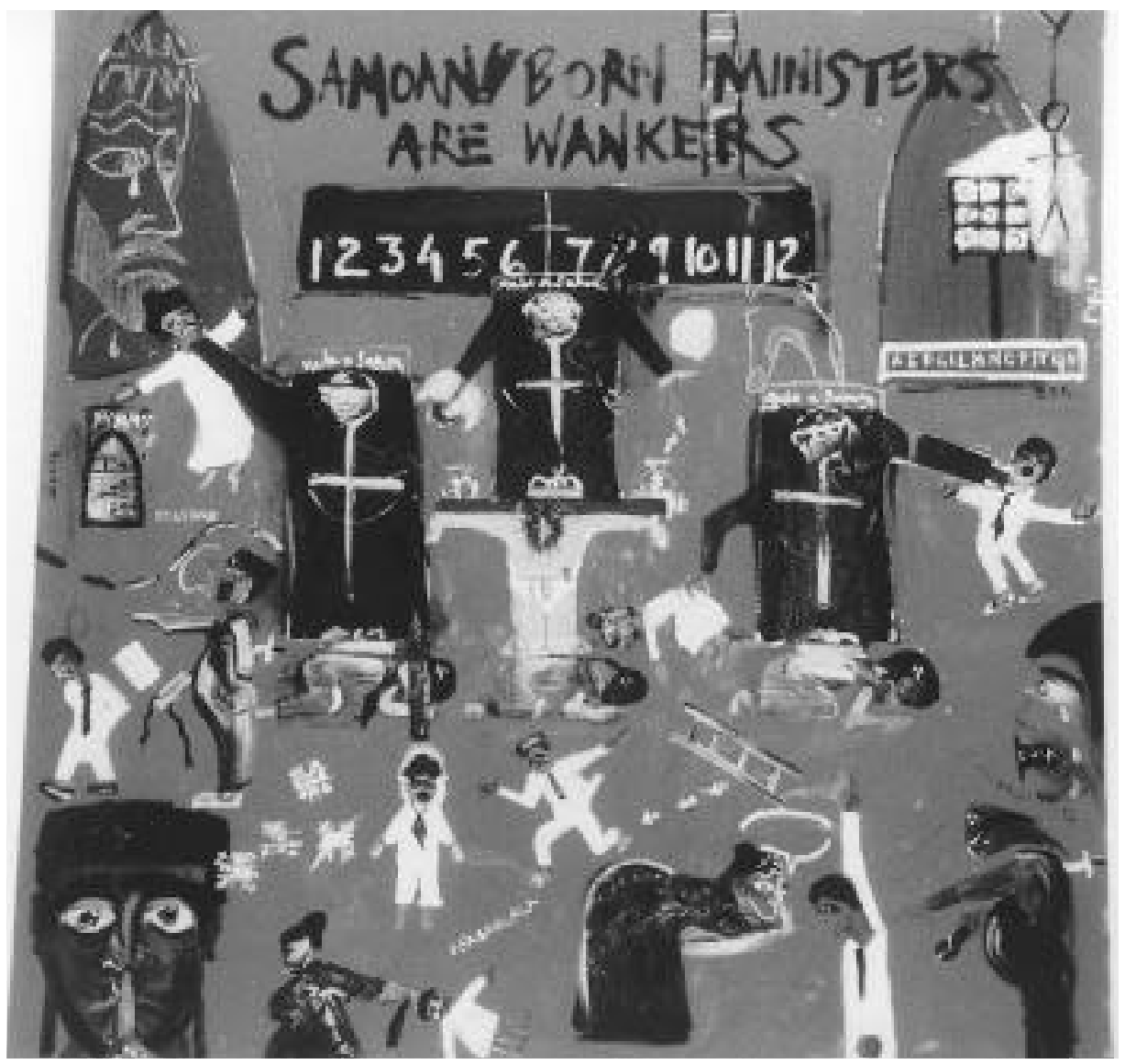

Figure 20. Honest to God, by Andy Lelei, oil on canvas, I 50 x I $50 \mathrm{~cm}$. (Courtesy of Casula Powerhouse Arts Centre, Casula, Sydney, Nsw. Margaret Jolly photo) 
ans that they asked for it to be taken down (figure 20). He refused. In a defiant alliance between an indigenous Australian and an Islander, Gordon Hookey said that if Andy's work came down his would too. They stayed up. But on the opening night, when the massed choirs of Sydney's Pacific communities assembled for the performance Angels from Heaven, the stairs to the upper gallery were closed, the offending paintings hidden by sound equipment, and the lights strategically directed on the women's exhibition of Weave and Judy Watson's gentler Aboriginal art on the ground below.

\section{Conclusion}

This paper has covered much, perhaps too much, ground-from the deserts of outback Australia, through the oceans and islands of the Pacific, and then back to the edge of Australia's eastern seaboard.Through the lens of museum openings and art events I have seen different "articulations" of indigeneity and diaspora, roots and routes in several countries. I do not mean to reduce these energetic individual creations and the allure of the brilliant art I witnessed to mere illustrations of different geopolitical contexts.Still, the similarities and differences between contexts in Vanuatu and New Caledonia, Aotearoa New Zealand and Australia are arresting-in the varying stress on indigenous autonomy or colonial entanglement and in how far Islanders are imagined as indigenous and/or diasporic.

Through this discussion of contemporary visual arts and architectures, I suggest something similar to Jim Clifford's stress on "articulation" in the politics of indigeneity $(480-484)$. The concept of articulation is rather more often applied to speech than to visual art. Like Clifford, I want to resist the idea that these art creations, spaces, and events are expressions of preexisting identities - neither the primordial authenticities of the past nor pragmatic postmodern ethnicities. Rather, what is articulated is not a preexisting "I/eye" of speech or vision, but a contingent and created collective "we" of speaking and looking, akin to a political coalition. There are differences in how "we" can be imagined-which derive from different sedimentations of the past and divergent contemporary coalitions of indigenous, settler, and migrant interests. These diverse articulations of roots and routes though variable, are not totally contingent. They are constrained by the particularity of the ground of being - not just in the material sense of earth and ocean-but how that ground, that country, amply holds both connections and ruptures between pasts, presents, and futures. 


\section{Notes}

I Both the skeletons of Mungo Lady and Mungo Man show evidence of ritual burial-she was cremated, and he was liberally dusted with ocher before being interred. The geologist Jim Bowler who first discovered the human remains in 1969 and 1974 dated them initially as 25,000 years and 32,000 years в P. Aboriginal custodians were clearly delighted by the more recent earlier dates, but large issues still remain because Aboriginal people often prefer to rebury remains rather than see them subject to scientific scrutiny (see Connellan 1996). Lake Mungo, in southwestern New South Wales, is located in a national park that is part of the Willandra Lakes World Heritage Area.

2 This refers to food foraged from land or water rather than store-boughtbut it can also more loosely refer to food, however procured, with an indigenous Australian source-such as kangaroo, wallaby, or emu meat, wild tubers, vegetables, and seeds or fish. In this region Aboriginal people caught fish, crayfish, and mussels and hunted emus, eastern-hare wallabies, bettongs, hairy-nosed wombats, Tasmanian devils, thylacines, and probably megafauna like the giant kangaroo, Procoptodon (Connellan I996, 70).

3 This resonates with Escobar's powerful critique of developmentalist discourse (1995), and the way in which it naturalizes a language not just of center and margin, core and periphery but of "First and Third Worlds," "North and South.”

4 Compare Clifford about "notions that have, in the western imaginary, long kept the Pacific 'out there' and 'back then" (476).

5 I do not by the order of this list imply a serial order of migration and settlement. The history of these movements is far more complicated and contested than I can distill here (see Spriggs 1997, 2000; Bellwood 2000).

6 I thank Donna Haraway for her observation at the symposium of how narratives of "deep time" of geological and climatic transformation or indigenous human histories are used to displace or subvert more recent settler histories of discovery and pioneering. I discern such narratives not just in the several papers by Epeli Hau'ofa cited, but in the symposium prospectus and in Vicente Diaz's paper as well as my own.

7 Diaz then reflects on the fact that the disappearance of the canoe in Guam has been associated with the death of culture through colonial domination there, in contrast with the persistence of the canoe on Polowat being associated with the persistence of culture there. I quote from the soundtrack: "The problem with these misconceptions is that the Chamorros get to have history but no culture ... while the Polowatese get to have culture but no history" (Sacred Vessels I997).

8 Born of Tongan ancestry, Hau'ofa grew up in Papua New Guinea, where 
his parents were missionaries. He was later educated at the Australian National University in anthropology and returned to Papua New Guinea in the I970s for his doctoral fieldwork among the Mekeo. He then taught at the University of the South Pacific in Suva, where he wrote much about development and authored a series of searing satires published as Tales of the Tikongs and Kisses in the Nederends. He has now, it seems, relinquished his earlier gifts as ethnographer, development specialist, critic, and comic and is writing more often in the voice of a sage or prophet. But the depth of his critical insight laced with sardonic wit perdures. He lives in Suva, Fiji, where he heads the Oceania Centre for Arts and Culture at the University of the South Pacific.

9 I do not impute a diminished world, but rather important differences in how worlds are imagined. My argument is similar to Clifford's notion of “'big enough' worlds" (482).

Io As I revise this paper, the violence of such confrontations is still ongoing after "coups" in both Fiji and the Solomon Islands.

I I Note also the movements of Gilbertese laborers to Hawaici.

I 2 Planters, recruiters, colonial agents, and some revisionist historians preferred the first view; missionaries, antislavery activists, and today especially the descendants of such laborers, prefer the second. This opinion was inscribed in the title if not the content of a Film Australia video Sugar Slaves (1994) and a I995 exhibition at the Vanuatu Cultural Centre.

I 3 This Act denied entry and the right of permanent residence on the grounds of race, although this policy was later made less direct through language tests or the imposition of skills requirements.

I4 The formal diplomatic opening occurred on 4 May 1998, but the workshops and exhibitions by visiting artists the next month, from I 6 June, constituted another, less formal, opening.

I5 But, some have observed, it is less accessible now to locals dropping in, since it is no longer in the central main street of town.

I6 Kaufmann has documented where objects from the Speiser collection are held, a few other sources of ni-Vanuatu material held in Basel, and the sites of other major collections of Vanuatu material ( I997).

I7 From Speiser's collection there were belts woven by Tannese men, brightly decorated in green, red, and black dentate designs, signaling the relative power and danger of the rank of the men who wore them. Another striking example of men's fiber art was a pandanus apron with feather decorations, the uniform of one of the highest suque grades in the Banks Islands.

I8 See for example Jolly (1992, I994), Bolton ( I999), Curtis ( 1999).

I9 In all indigenous languages of this archipelago there is a pervasive use of tropes that juxtapose and connect trees and canoes, banyans and birds (Bonnemaison 1986; Jolly 1994). In a recent paper I stress that what is devalued is mere 
floating or reactive movement (I999b); on the other hand, strategic movement from a secure base is valued, and indeed expected for a strong man ples. Thus, in much talk about migrants to town, those who go for jobs or education are valued, but those who are unemployed are denigrated as drifters, wandering the roads of Port Vila. These attitudes and the broader situation of unemployed youth in Port Vila are poignantly portrayed in the film Kilim Taem (1998).

20 The latest census suggests that Kanak number about 85,000 or 44 percent of a total of 200,000. The other main groups are Europeans 34 percent (mainly Caldoches), Polynesians I 2 percent (mainly workers from Wallis and Futuna and some Tahitians), Indonesians 3 percent, Melanesians (ni-Vanuatu especially), IndoChinese, Antilleans, and Arabs. Given current birthrates, the combined total of Kanak and Melanesians, most of whom are pro-independence, could be a majority by 2010 (Brown I998, 5).

2I This was projected as 1998 by the Matignon Accords but was deferred (by the Noumea Accords signed by French Prime Minister Lionel Jospin on 5 May I998) to sometime between 2013 and 2018 , arguably because of the twin fears of a return to the violence of the I980s and the prospect of economic collapse without French aid (which presently totals about 4.5 billion French francs per year; Brown 1998, 3-4). It is claimed that this is to allow a gradual devolution of power to the provinces and a concerted effort to improve health, education, and transport and to prepare Kanak to lead. Some analysts see these accords as increasing rather than decreasing French influence through instituting a more capillary, provincialized power.

22 Tjibaou was a charismatic leader of the FLNKS (Front de Libération Nationale Kanak Socialiste), part of the broader Kanak nationalist movement. He came from Hienghène in the north, where he became mayor in the r97os. Throughout his religious training as a Jesuit priest and as a political leader he lived mainly in Noumea and, like many indigenous leaders of the French Pacific, was a frequent visitor to France. As Clifford stresses (468-469,47 I, 478), though a strong nationalist, Tjibaou believed in negotiating interdependence with the French as well as independence. He and his deputy Yeiwéné Yeiwéné were assassinated by Djubelly Wéa, a pro-independence Kanak who considered Tjibaou's stance too conciliatory. Wéa was then killed by Tjibaou's bodyguard. Tjibaou's writings have been posthumously published in a superb volume edited by Alban Bensa and Eric Wittersheim (Tjibaou I996).

23 This and all subsequent quotes in this section are taken from the soundtrack of the film made about the artistic opening of the Tjibaou Cultural Centre, Ngan Jila-House of Riches (1999) by Renata Schuman and Andrew Bliss.

24 There was a series of articles in Australian newspapers, magazines, and architectural journals-for example Anne Suskind (1998) in the Good Weekend of the Melbourne Age and Ron Cerebano (1998) in the Canberra Times. These 
typically celebrated the architecture and its affirmation of Kanak culture while commenting on the continuity of French colonialism and its huge expense to the French state. For example Suskind's article "Grand Piano" commented on the proximity of the center to "Nouméa la Blanche, white Nouméa," "Renzo Piano's series of weathered timber 'huts' celebrate Kanak culture within cooee of the colonial capital" (I998, 40). The reportage in the New Caledonian and French press was less ambiguous, although there were also some local complaints about expense.

25 The site is about sixteen kilometers from Noumea, although visible from many parts of the town. It is proximate to the private enclave of Tina, an upperclass real estate development, with an exclusive golf course nearby. Tina Peninsula was the site of the huge cultural and political event, Melanesia 2000 Festival, organized by Jean-Marie Tjibaou in 1975 .

26 Suskind noted how this effect is created by the fact that the outer staves are of different lengths and are unevenly placed. This not only creates the aesthetic sense of vibration, but "the gaps between the staves allow the wind to pass through: a solid face would create too much resistance" $(1998,40)$. She also catalogued, beyond Piano's intended metaphor, the abundant associations of the building: a petrified forest, protective cradles, bomb shelters, water tanks, or in Lionel Jospin's view a space shuttle poised for takeoff!

27 Compare the statement from Tjibaou, quoted by Clifford (484). As he embraced the landscape of village, valleys, and mountains with the sweep of his hand, he said "Mais, c'est ça la maison," "But that's the house."

28 An architect from the Australian group that had come second to Piano's company in the tendering stressed, no doubt with partisan intent, how his firm lays stress on using local materials wherever possible and ensuring that replacement parts such as nails and screws are readily available from local building suppliers and hardware stores. By contrast, he observed, many of the smaller components of Piano's building were imported and relied on high-cost European technology.

29 These three stones were inspired by a sense of regional connection in the common heritage of Lapita pottery. The stones were broken and reassembled like sherds found by archaeologists. Said Grahame, "I split the stones and put them back together again as a metaphor for the destruction and reconstruction of these cultures" (Grahame in Tjibaou Cultural Centre 1998, 90).

30 This was a comment made by Emmanuel Kasarhérou in response to a question I posed at the Pacific History Association meetings in Canberra, 29 June 2000.

3I Brown noted that young Kanak who turned up for the performances of Kaneka music (a style developed in the I980s that combines reggae, Kanak percussion, and gospel melodies) were disappointed to discover the shows were not 
free, and since they could not afford the Ioo franc fee, left. I should note that the center has also been a venue not just for the visual arts, dance, and music but theatre, with performances of Cendre de Sang (Blood Ashes) by the Kanak playwright Pierre Gope and Le Sentier (The Path) by Nicolas Kurtovitch, poet, playwright, and author, whose maternal family came to New Caledonia in the midnineteenth century (see Muckle nd). Although recognizing the importance of the Tjibaou Cultural Centre in the recent cultural effervescence in Noumea, Brown noted that the majority of those attending the cultural festivals were European, not Kanak, and that the center is inaccessible for those who have to rely on public transport. He suggested, "the Centre does not necessarily feel home to all Kanaks" (I998, I6).

32 The name Te Papa (an abbreviation of Te Papa Tongarewa, meaning treasures of Mother Earth) has become the preferred designation, along with the English mistranslation "our place." C K Stead offered a searing approach to the meaning of Te Papa, as denoting "an ongoing cost for no useful return," waste, and extreme bad taste, "purposeful vulgarisation of the arts. ... In general the term 'Te Papa' would signal the Disneyfication of the arts, Maori and Pakeha" (1998, 3I).

33 This, a commissioned art work by Milan Mrkusich, has been criticized by many as garish, I970s retro (see Robinson I998, 59).

34 These interactive exhibits have been lauded by some as making the museum more accessible and modern (Campbell 1998; Becton 1998; Bennett I998), while other commentators have lamented what they saw as frivolity more appropriate to a theme park or a shopping mall than a museum (Dalrymple 1999; Dutton 1998; Stead 1998). Dalrymple's scathing review in the New Statesman opined, "Sensation is much more democratic than information." "Malling," it seems, was part of the architectural intention, with the use of a central atrium for easy visitor flow coupled with many escalators and elevators, and a plenitude of strong, sometimes hectoring signs and glitzy surfaces (Fraser 1998, 5). Skinner suggested that museums do not so readily throw off their past specters or historical legacies with consumeristic hype or "tools of the future" (1998).

35 Kent saw this wedge as a "particularly questionable" expression of biculturalism as it implies a divide between cultures as much as a coming together $(1998,84)$.

36 In the secluded upper gallery spaces of the Ilott room, where temporary exhibits are on display, there is a sense of a quiet dedication to "high art," and an appeal to what Webster called "traditional art audiences" ( 1998,32 ).

37 Some reports suggested that at some point it was planned for upstairs, linking the M ori and Mana Pasifika displays (Williams I998, I7).

38 Alfred Hunkin, founder of the Samoan department at Victoria University 
in Wellington said "Understandably Maori were pushing for a bicultural focus and we were saying, 'That's fine but don't forget we are in the Pacific.' I mean, the Pacific Ocean is absolutely paramount in this country. Maori came from the Pacific" (quoted in Williams 1998, I7). Auckland academic and author Albert Wendt also criticized the lack of a sense of Pacific origin and connection, "They need to go deeper than merely shoving Pacific culture into a small box" (quoted in Williams I998, I7). Te Papa has a huge Pacific Island collection-2,500 weapons, 2,000 personal adornments, I,000 tapa, and 300 vaka (canoes) - of which only a tiny portion is on display (Rose 1998). The Auckland Museum has an even larger collection and, in recent time under the curatorship of Fuli Pereira (previously of Te Papa) has organized two large exhibits, Masterpieces and Pacific Lifeways.

39 Ken Gorbey, Te Papa's research and development manager, suggested that criticism of the Pacific exhibits comes from older people and museum curators not adapting to the representation of the present. "Many museums become too tied up in the ethnographic past and tend to dismiss ethnic races as seemingly extinct. Many of these cultures are alive and well, and they are often very different from the way they used to be. Pacific Island people are a living people, and that is precisely why we try and tie them to the recognisable present as much as we can" (Williams I998, I8). It seems the "recognisable present" is that which exists in New Zealand.

40 A study of the visitor profile suggests that the museum attracted 25 percent repeat visitors after a month, including international and domestic tourists. It also showed it was attracting people proportionately from all ethnic groups in Aotearoa New Zealand but especially attracting those who did not usually visit museums and art galleries (Fraser 1998, I 5 ).

4I The building cost NZ\$3I7 million to build, and Te Papa has funding of NZ\$I 6 million a year from the government. But there is a gap between the estimated running cost and the government budget that had to be bridged by raising NZ \$50 million from sponsorship and commercial activities in five years. Thus there is a claim of "deliberate underfunding" (Welch 2000, 36-38).

42 In 1996 the proportions were I4.5 percent identifying as Maori, 80 percent as Pakeha, 5.6 percent as Pacific Islanders, 2.2 percent as Chinese, and I.I percent as Indian.

43 It does now. After decades of debate and government indecision and inaction, a museum has been built in Canberra, proximate to the Australian National University and facing several national monuments across Lake Burley Griffin. It was opened on I I March 200 I by Prime Minister John Howard. 


\section{References}

\section{Print}

Becton, Neal

I998 Te Papa: A Virtual New Zealand. Evening Post, 3 October.

Bellwood, Peter

2000 Footsteps from Asia. In The Pacific Islands: An Encyclopedia, edited by Brij V Lal and Kate Fortune, 53-58. Honolulu: University of Hawai'i Press.

Bennett, Joe

I998 Kids Delight in Te Papa's Energetic Chaos. Evening Post, 8 July.

Bolton, Lissant

I996 Tahigogona's Sisters: Women, Mats and Landscapes on Ambae. In Arts of Vanuatu, edited by Joël Bonnemaison and others, I I 2-I I9. Bathurst, Nsw: Crawford House Publishing.

Bolton, Lissant, editor

I999 Fieldwork, Fieldworkers: Developments in Vanuatu Research. Special issue of Oceania 70 (I).

Bonnemaison, Joël

I986 La dernière île. Paris: Arlea/ors tom.

Bonnemaison, Joël, and others, editors

I994 Arts of Vanuatu. Bathurst, Nsw: Crawford House Publishing.

Bossley, Pete

I998 Te Papa: An Architectural Adventure. Wellington: Te Papa Press.

Brown, Peter

I998 New Caledonia: Strangers in Paradise, Stranger than Paradise. Paper presented at State, Society and Governance Seminar, Australian National University, I 2 August.

Campbell, Sophie

I998 Come on Down and Visit Our Place. The Times Weekend. 20 June.

Clifford, James

I997 Routes: Travel and Translation in the Late Twentieth Century. Cambridge, MA: Harvard University Press.

Cerebano, Ron

I998 Noumea Center Focuses on Kanak Culture. Canberra Times, I5 June.

Connellan, Ian

I996 The Life in Mungo. With photographs by Barry Skipsey. Australian Geographic, October-December, 60-83.

Curtis, Tim

I999 Tom's Tambu House: Spacing, Status and Sacredness in South Malakula, Vanuatu. In Fieldwork, Fieldworkers: Developments in Vanuatu 
Research, edited by Lissant Bolton, 56-71. Special issue of Oceania 70 (I).

Dalrymple, Theodore

I999 An Amusement Arcade Masquerading as a Museum. New Statesman, I2 February, 32-33.

Dening, Greg

I998 Endeavour and $H k$ le $a$. In Readings/Writings, by Greg Dening, ı०0-I 8 . Melbourne: Melbourne University Press.

Dutton, Denis

I998 State Treasure or Dog's Breakfast. The Dominion, 2I May, I I.

Escobar, Arturo

I995 Encountering Development: The Making and Unmaking of the Third World. Princeton, NJ: Princeton University Press.

Finney, Ben

I994 Voyage of Rediscovery: A Cultural Odyssey through Polynesia. Berkeley: University of California Press.

Fraser, Virginia

I998 Te Papa Tongarewa. Art Monthly Australia I Io (June): I3-I6.

Geertz, Clifford

I998 Deep Hanging Out. New York Review of Books, October 1998.

Hau'ofa, Epeli

I994 Our Sea of Islands. The Contemporary Pacific 6:I48-I6I.

I998 The Ocean in Us. The Contemporary Pacific Iо: 39I-4IO.

2000 Epilogue: Pasts to Remember. In Remembrance of Pacific Pasts: An Invitation to Remake History, edited by Robert Borofsky, 452-47I. Honolulu: University of Hawai'i Press.

Huffman, Kirk

I996 Series of Incised Bamboo and Cane Ornaments from the Torres and Banks Islands, Ambae and Maewo. In Arts of Vanuatu, edited by Joël Bonnemaison and others, 238-239. Bathurst, Nsw: Crawford House Publishing.

Jolly, Margaret

I992 Custom and the Way of the Land: Past and Present in Vanuatu and Fiji. Oceania 62 (4): 330-354.

1994 Women of the Place: Kastom, Colonialism and Gender in Vanuatu. Reading and Chur: Harwood Academic Publishers.

I999a "Our Part of the World": Indigenous and Diasporic Differences and Feminist Anthropology in America and the Antipodes. Communal/Plural 7 (2): 195-2I2.

I999b Another Time, Another Place. Oceania 69 (4): 282-299. 
Kasarhérou, Emmanuel, and Béalo Wedoye

I998 Guide to the Plants of the Kanak Path. With Roger Boulay and Claire Merleau-Ponty. Noumea: Centre Culturel Tjibaou/Ngan Jila, Agence de développement de la culture Kanak.

Kaufmann, Christian

I997 Vanuatu: Kunst aus der Südsee. Basel: Christoph Merian Verlag.

Kent, Rachel

I998 Museum of New Zealand. Art AsiaPacific 20:84-85.

Muckle, Adrian

nd The Noumea Accords and the Trope of "Misunderstanding" in New Caledonian History and Literature. Unpublished paper.

Pettman, Jan

I992 Living in the Margins: Racism, Sexism and Feminism in Australia. Sydney: Allen \& Unwin.

Rawlings, Greg

I999 Villages, Island and Tax Havens: The Global/Local Implications of a Financial Entrepot in Vanuatu. Canberra Anthropology 22 (2): 37-50.

Reardon-Finney, Frances

I999 "I Thought It Would Be Heaven": Migration, Gender and Community amongst Overseas Tongans. MA thesis, anthropology, Australian National University.

Regenvanu, Ralph

I997 Preface. In Vanuatu: Kunst aus der Südsee, edited by Christian Kaufmann, 9-I I. Basel: Christoph Merian Verlag.

Rees, Simon

I998 Lively Arts: Te Pakeha. Metro (February) Io I-IO3.

Robinson, Simon

1998 Where the Heart Is. Time, I 6 February.

Roger, Warwick

I998 Forget the Future, Check Out the Past. Evening Post, I 5 June.

Rose, Jeremy

I998 Raiders of the Lost Vaka. Dominion, 3 November, Io.

Shineberg, Dorothy

1999 The People Trade: Pacific Island Laborers and New Caledonia I8651930. Pacific Islands Monograph Series I6. Honolulu: Center for Pacific Islands Studies and University of Hawai'i Press.

Skinner, Damian

I998 Wellington: Te Papa. Art New Zealand 87 (Winter): 28-29.

Spriggs, Matthew

I997 The Island Melanesians. Oxford: Blackwell.

2000 Lapita Culture. In The Pacific Islands: An Encyclopedia, edited by Brij V Lal and Kate Fortune, 58-59. Honolulu: University of Hawai'i Press. 
Stead, C K

I998 Te Papa: A Linguistic Approach. Art News I 8 (2): 3I.

Suskind, Anne

1998 Grand Piano. Melbourne Age, 6 June.

Tjibaou, Jean-Marie

I996 La Présence Kanak, edited by Alban Bensa and Eric Wittersheim. Paris: Editions Odile Jacob.

Walter, Annie

I996 The feminine art of mat-weaving on Pentecost. In Arts of Vanuatu, edited by Joël Bonnemaison and others, Io0-I זо. Bathurst, NSw: Crawford House Publishing.

Webster, Kathryn I998 The Big Picture: Our Place, Our Art. Art News I 8 (I): 30-32.

Welch, Denis

2000 Party at Our Place: Bring a Plate, and \$ I 7 m. Listener, 26 February.

Williams, Perry

I998 The Lost Vaka. Loop I7-I8.

\section{Films}

Kilim Taem

I998 Directed by Anthony Mullins and Randall Wood. 50 minutes, color, vHs. Young Peoples Project, Vanuatu Cultural Centre, Port Vila. Produced by Jan Cattoni. Distributed by Unicef, Fiji.

Ngan Jila: House of Riches

I998 Directed by Renata Schuman. Produced by Renata Schuman and Andrew Bliss. Tjibaou Cultural Centre, Port Vila.

Sacred Vessels: Navigating Tradition and Identity in Micronesia

I997 Written and directed by Vicente Diaz. Produced by Vicente Diaz and Christina Taitano DeLisle, Moving Island Productions. 28 minutes, color, VHS, NTSC, and PAL. Distributed by Pacific Islanders in Communications, Honolulu.

Sugar Slaves: The Secret History of Australia's Slave Trade

I994 Directed by Trevor Graham. Produced by Penny Robins. Film Australia. Sydney.

\section{Abstract}

This paper starts with a playful inter rogation of being "on the edge" of California from the perspective of a millennial experience "in the center" of Australiapartly to suggest my own location, but also to suggest how imagined geographies 
of edges and centers, of peripheries and interiors are geopolitical mirages. It then moves to a consideration of how representations of deep time, in being "on the edge" or inhabiting "a sea of islands" relate to the contemporary politics of indigeneity and diaspora in the Pacific. While acknowledging the differences between Islanders of different regions and countries, the co-presence of the values of "roots" and "routes" is stressed. The varied relation of indigeneity and diaspora is explored through visual arts displayed in museums and cultural festivals in Vanuatu, New Caledonia, Aotearoa New Zealand, and Australia.

KEYWORDS: anthropology, cultural studies, culture, history, Pacific studies, representation, visual arts 